\title{
Molecular Transformation of 2-Methylazulenes: An Efficient and Practical Synthesis of 2-Formyl- and 2-Ethynylazulenes
}

\author{
Taku Shoji, ${ }^{[a]}$ Takanori Araki, ${ }^{[a]}$ Nanami lida, ${ }^{[a]}$ Yoshiaki Kobayashi, ${ }^{[a]}$ Akira Ohta, ${ }^{[a]}$ Ryuta Sekiguchi, ${ }^{[a]}$ \\ Shunji Ito, ${ }^{[b]}$ Shigeki Mori, ${ }^{[c]}$ Tetsuo Okujima, ${ }^{[\mathrm{d}]}$ and Masafumi Yasunami (Deceased) ${ }^{[\mathrm{e}]}$
}

\begin{abstract}
Formylazulene derivatives were obtained in good yields by the reaction of 2-methylazulenes with $\mathrm{N}, \mathrm{N}$-dimethylformamide dimethyl acetal, followed by oxidative cleavage of intermediately formed enamines with $\mathrm{NalO}_{4}$. Vilsmeier formylation of 1-phenyl-3methylazulenes also afforded the corresponding 2-formylazulenes in moderate yields. In a 2-methylazulene derivative having a formyl group at the 1-position, self-condensation reaction was also observed by the treatment with sodium methoxide to produce a trans-1-(azulen-1-yl)-2-(azulen-2-yl)ethylene derivative, of which structure was clarified by single crystal X-ray analysis. 2Formylazulenes obtained by the reaction were also transformed to 2ethynylazulenes in good yields by modified Seyferth-Gilbert reaction. The reactivity of 1-iodoazulene bearing 2-formyl function toward palladium-catalyzed cross-coupling reactions was also examined.
\end{abstract}

\section{Introduction}

Azulene, which is one of the non-alternating $10 \pi$ electron aromatic compounds, has attracted the interest of many research groups owing to its unusual properties as well as its beautiful blue color. Thus, various functionalization methods for azulene and its derivatives have been reported by many researchers. ${ }^{[1]}$ Functionalization of 1 - and/or 3-positions of azulene derivatives have readily achieved by electrophilic substitution reactions because these sites have high reactivity toward a variety of electrophiles. ${ }^{[1,2]}$ On the other hand, introduction of functional groups to the other positions of azulene

[a] Prof. Dr. T. Shoji, T. Araki, N. lida, Y. Kobayashi, Prof. Dr. A. Ohta R. Sekiguchi,

Department of Material Science

Graduate School of Science and Technology

Shinshu University, Matsumoto 390-8621, Nagano (Japan)

E-mail: tshoji@shinshu-u.ac.jp

http://soar-rd.shinshu-u.ac.jp/profile/en.gmShOakh.html

[b] Prof. Dr. S. Ito

Graduate School of Science and Technology

Hirosaki University, Hirosaki 036-8561, Aomori (Japan)

[c] Dr. S. Mori

Advanced Research Support Center, Ehime University,

Matsuyama 790-8577, Ehime (Japan)

[d] Prof. Dr. T. Okujima

Department of Chemistry and Biology

Graduate School of Science and Engineering

Ehime University, Matsuyama 790-8577, Ehime (Japan)

[e] Prof. Dr. M. Yasunami (Deceased)

Department of Chemical Biology and Applied Chemistry, College of

Engineering, Nihon University, Koriyama 963-8642, Fukushima (Japan)

Supporting information for this article is given via a link at the end of the document.((Please delete this text if not appropriate)) ring has often encountered some difficulties, although the effective functionalization methods at their 5- and/or 7-positions have reported..$^{[3,4]}$

2-Formylazulene derivatives are versatile starting materials that can be converted into azulene-substituted $\alpha$-hydroxyketones, diketones, imines, hydrazones, alkenes, alkynes, and heterocyclic compounds. ${ }^{[5]}$ Even the synthesis of 2formylazulenes with a simple structure, there is no straightforward method because of the difficult availability of the starting materials and/or the multi-step synthesis required in addition to the low product yields. In early years of azulene chemistry, Hafner and Moritz reported that 1,3-dimethylazulene undergoes the electrophilic substitution reaction under the Vilsmeier formylation conditions to afford the corresponding 2formylazulene derivative in $21 \%$ yield.${ }^{[6]}$ In 1980 , Takase and coworkers reported the preparation of 2-formylazulene by using $\mathrm{OsO}_{4}$ oxidation of 2-styrylazulene. ${ }^{[7]}$ However, this method requires the starting material which is difficult to synthesize, and the yield of the product is quite low (13\%). Although Murafuji et al. have also reported the synthesis of 2-formylazulene by the reduction of azulene-2-carboxamide with diisobutylalminium hydride (DIBAL) in $42 \%$ yield, preparation of the azulene-2carboxamide precursor required multiple-step synthetic pathway. ${ }^{[8]}$ We have also reported the preparation of 2formylazulene by the reaction with 2-azulenyllithium and magnesium reagents with DMF in excellent yields $(89 \%$ and $99 \%$ yields, respectively), but preparation of 2-iodoazulene, which is difficult to access, is required to prepare the azulenyl metal reagents. ${ }^{[9]}$ 2-Formylazulene have also been prepared by Yasunami-Takase's azulene synthesis,4d but the preparation method is not applicable to the other functional derivatives, straightforwardly, because of the quite low applicability of the functional group on the $2 \mathrm{H}$-cyclohepta[b]furan-2-one precursors. When electron-withdrawing group is substituted to the precursor, the reaction competes with the side reaction to give aminopentafulvenes. ${ }^{[10]}$ From the situation mentioned above, the development of a synthetic procedure by a short step with readily available starting materials should bring great benefits to the practical synthesis of 2-formylazulenes.

Oxidative cleavage of the enamines, which have been prepared by the reaction of electron-deficient aromatic compounds at their methyl function with $N, N$ dimethylformamide dimethyl acetal (DMFDMA), with $\mathrm{NaIO}_{4}$ is a general procedure for the transformation of the methyl group to formyl function in the aromatic compounds. ${ }^{[11]}$ In azulene chemistry, 4-formyl- ${ }^{[12]}$ and 6-formylazulene ${ }^{[13]}$ derivatives have been prepared from the corresponding methylazulenes by using the similar procedure. However, there is no example adopting this method to the synthesis of 2-formylazulenes, despite the electron-withdrawing nature at the 2-position as 
similar with that at the 4- and 6-positions. Since 2methylazulenes could be readily synthesized in high yields by Yasunami-Takase's procedure, an efficient and practical synthetic procedure of 2-formylazulenes should be established, if the method can be applied.

Herein, we describe a novel synthetic approach to 2formylazulenes by the reaction of 2-methylazulenes with DMFDMA, followed by the oxidative cleavage of intermediately formed enamines with $\mathrm{NalO}_{4}$. As another method, the synthesis of 2-formylazulenes by the Vilsmeier reaction of 1-phenyl-3methylazulene derivatives was also investigated. Furthermore, we found the formation of trans-alkene derivative substituted by two-azulenyl groups by the self-condensation reaction under basic conditions in the course of studying the reactivity of 1formyl-2-methylazulene derivative. Transformation of 2formylazulenes to 2-ethynylazulenes was also examined by modified Seyferth-Gilbert reaction conditions. These results demonstrate the usefulness of the 2-methylazulene derivatives as starting materials that can be converted to various functional azulene derivatives.

\section{Results and Discussion}

Synthesis of 2-formylazulenes: For the synthesis of 2formylazulenes, we adopted the reaction of several 2methylazulenes with DMFDMA to give the enamine intermediates, followed by the oxidative cleavage of intermediately formed enamines with $\mathrm{NalO}_{4}$. Since the enamine intermediates obtained by the reaction were instable and readily decomposed by chromatographic purification process, the oxidative cleavage with $\mathrm{NalO}_{4}$ was performed without the isolation of the enamine intermediates. However, in the case of the reaction of $\mathbf{5}$, suitable single crystal for single crystal X-ray structure analysis was exceptionally obtained from the crude enamine product. Thus, the crystal structure of the enamine intermediate was clarified by the single crystal X-ray structure analysis (Figure 1). The yield and structure of 2-formylazulenes obtained by the reaction are summarized in Table 1 .

Table 1. Synthesis of 2-formylazulenes from 2-methylazulene derivatives.
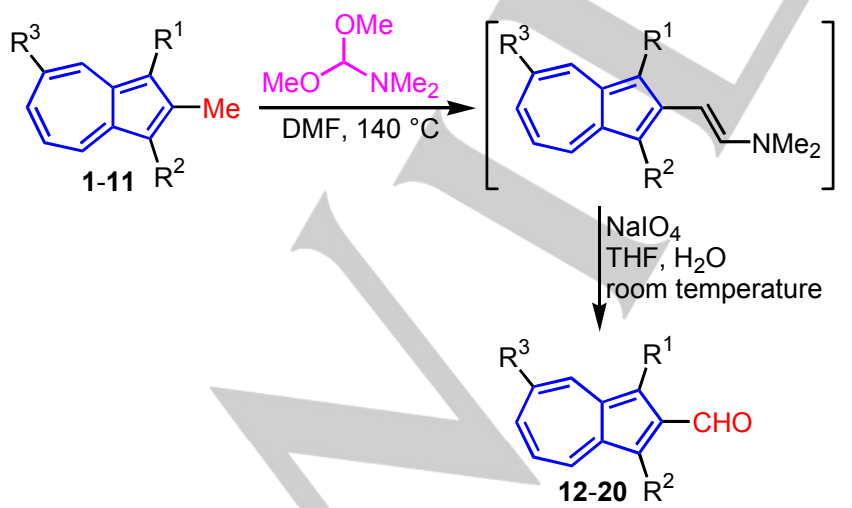

Entry Substrate

11

2<smiles>COC(=O)c1c(C)cc2cccccc1-2</smiles><smiles>COC(=O)c1c(C=O)cc2cccccc1-2</smiles><smiles>COC(=O)c1c2cccccc-2c(C(C)=O)c1C</smiles>

13<smiles></smiles>

4<smiles>COC(=O)C1=C(C=O)C(C=O)=C(C=O)C1=C1C=CC=CC2=C(C)C(C)=C(C=O)C21</smiles>
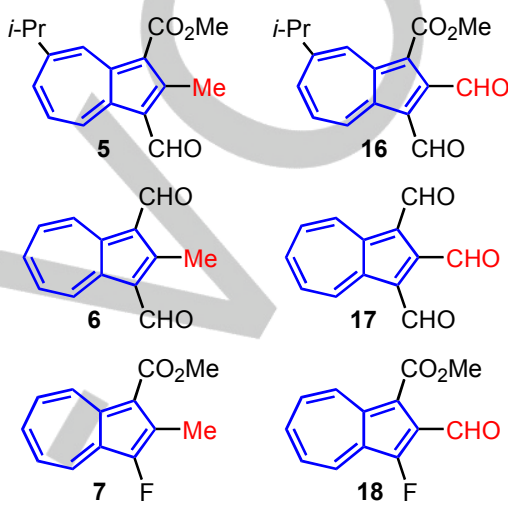

8
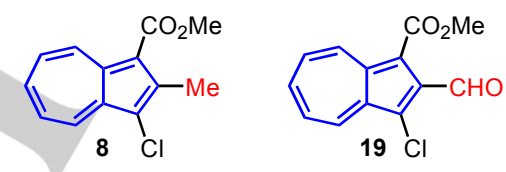<smiles>COC(=O)c1c2cccccc-2c(Br)c1C</smiles><smiles>COC(=O)c1c2cccccc-2c(I)c1C</smiles>

10

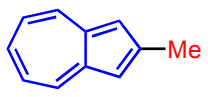

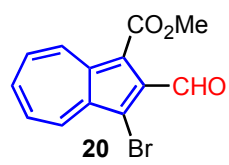<smiles>CC(=O)c1c2cccccc-2c(I)c1C=O</smiles><smiles>O=Cc1cc2cccccc-2c1</smiles>

22 [a] Two-step yield from 2-methylazulenes 1-9.

In general, the reaction of 2-methylazulene derivatives having electron-withdrawing substituents at their 1,3-positions produced the corresponding 2-formylazulenes in good yields. On the other hand, this reaction was not effective in the cases of 2 methylazulenes with either bromine or iodine substituent, since the reaction competed with the decomposition of the substrate.

The reaction of 1 with DMFDMA at $140{ }^{\circ} \mathrm{C}$ gave crude enamine intermediate as brown oil (Table 1). The oxidative cleavage of the enamine intermediate with $\mathrm{NalO}_{4}$ afforded 2 formylazulene 12 in 54\% yield (entry 1). As shown in Table 1, 2 formylazulenes 13-19 were also obtained by the reaction of 2 methylazulene derivatives 2-8 with DMFDMA, followed by the oxidative cleavage with $\mathrm{NalO}_{4}$ in good to excellent yields 
(61-90\%, entries 2-8). In particular, two-step reaction of 2methylazulene derivatives 4-7, in which the electronwithdrawing group was substituted at their 1,3-positions, produced the corresponding 2-formylazulenes in excellent yields. These results suggested that the enamine intermediates formed by the reaction of 4-7 are more likely formed compared to those of the other derivatives, since the acidity of the methyl group at the 2-position was increased by the electron-withdrawing groups at their 1,3-positions. On the other hand, the reaction of 9 and 10 having either bromine or iodine substituent with DMFDMA resulted in decomposition, owing to the thermal instability of the precursors 9 and 10 (entries 9 and 10). Moreover, no reaction was observed to form an enamine intermediate in 2methylazulene (11) (entry 11). This implies the requirement of an electron-withdrawing group at least on azulene ring to afford the enamine intermediate.

These new 2-formylazulenes were fully characterized on the basis of their spectral data, as summarized in the Experimental Section. The signal assignment of ${ }^{1} \mathrm{H}$ NMR was accomplished by COSY experiment. HRMS of the new compounds ionized by MALDI, EI or FAB showed the expected molecular ion peaks. The structure of 16 was also confirmed by single-crystal X-ray structural analysis, since the suitable single crystals were obtained by slow evaporation from $\mathrm{MeOH}$ (Figure 2 ). These results show the correctness of the structure of synthesized 2-formylazulenes.

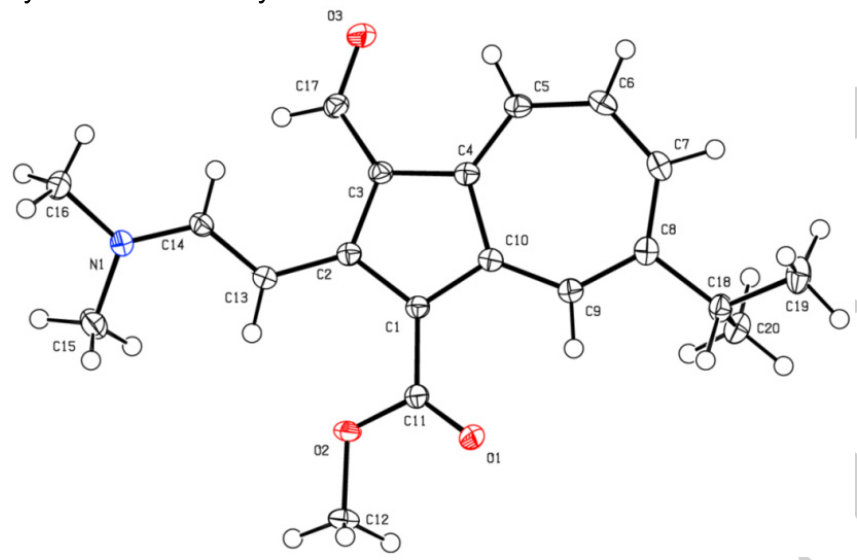

Figure 1. ORTEP Drawing for the enamine intermediate obtained from the reaction of $\mathbf{5}$; Ellipsoids are drawn at $50 \%$ probability. ${ }^{[14]}$

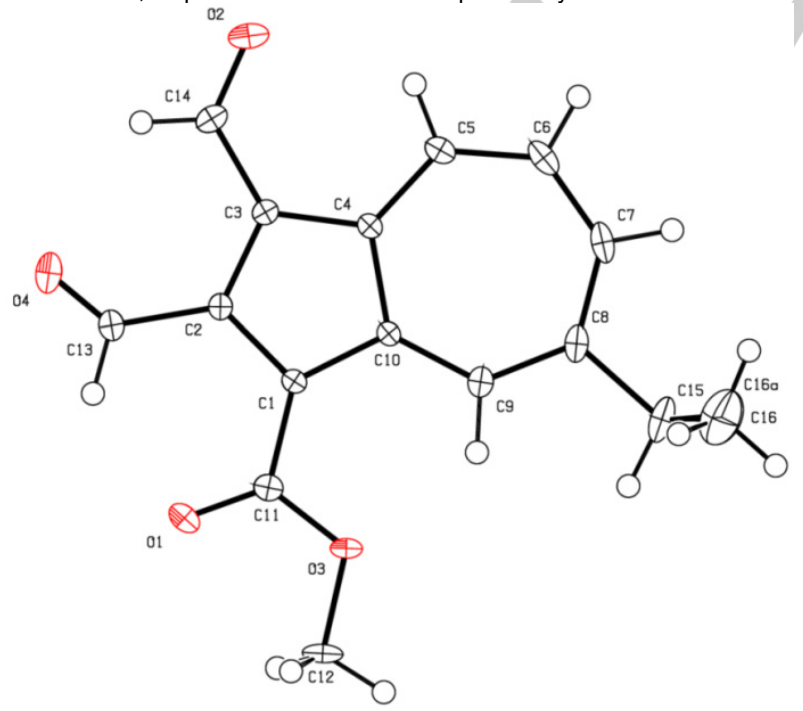

Figure 2. ORTEP Drawing for 2-formylazulene 16; Ellipsoids are drawn at $50 \%$ probability. ${ }^{[14]}$

By utilizing the high acidity of the methyl proton at the 2position, the synthesis of cyclooctatetraene derivative fused by two azulene rings was investigated by the aldol-type condensation reaction on the 1-formyl group. In order to prevent the solubility problem of the product by $\pi-\pi$ stacking, 2methylazulene derivative 5 , which was substituted by the bulky isopropyl group, was selected as a starting material.

Contrary to the expectation, the reaction of compound $\mathbf{5}$ with sodium methoxide in methanol afforded trans-alkene 23 with two-azulenyl substituents as a single product in $70 \%$ yield, instead of the presumed cyclooctatetraene derivative (Scheme 1). This fact indicates that the self-condensation reaction of the methyl and formyl groups between the two azulene rings produces the thermodynamically stable trans-alkene product prior to the cis-alkene product. Therefore, the cyclooctatetraene derivative, which requires the formation of cis-alkene intermediate, should not be generated under this condition.

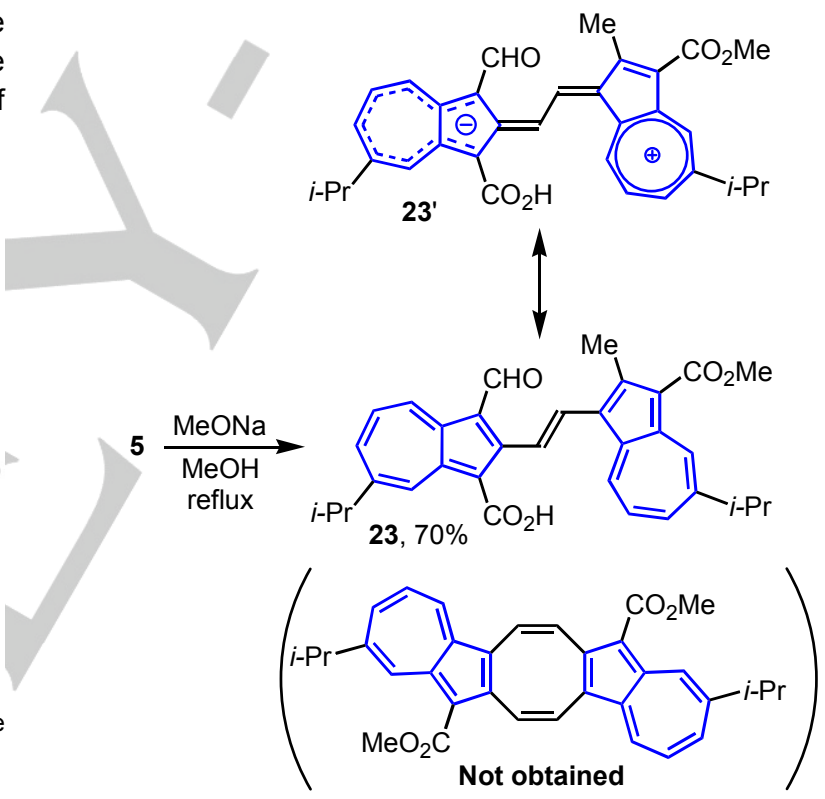

Scheme 1. Synthesis of 23 by the self-condensation reaction of 5

The ${ }^{1} \mathrm{H}$ NMR spectrum of alkene 23 showed proton signals of the both azulene rings, individually. The coupling constant of the alkene protons was observed as $J=16.6 \mathrm{~Hz}$, which supported the trans-alkene structure of 23. Furthermore, the trans-alkene structure of $\mathbf{2 3}$ was also confirmed by single crystal X-ray structure analysis (Figure 3 ). Although the bond length between the azulene ring and the methyl carbon at the 2position showed almost the same length (C14-C28, $1.501 \AA)$ toward the ordinary single bond, the single bonds (i.e. C2-C11 and $\mathrm{C} 12-\mathrm{C} 13)$ exhibited shorter bond length. This result indicates the resonance effect between the 1-azulenyl and 2azulenyl groups to form $\mathbf{2 3}$ ' through the alkene moiety as shown in Scheme 1. 


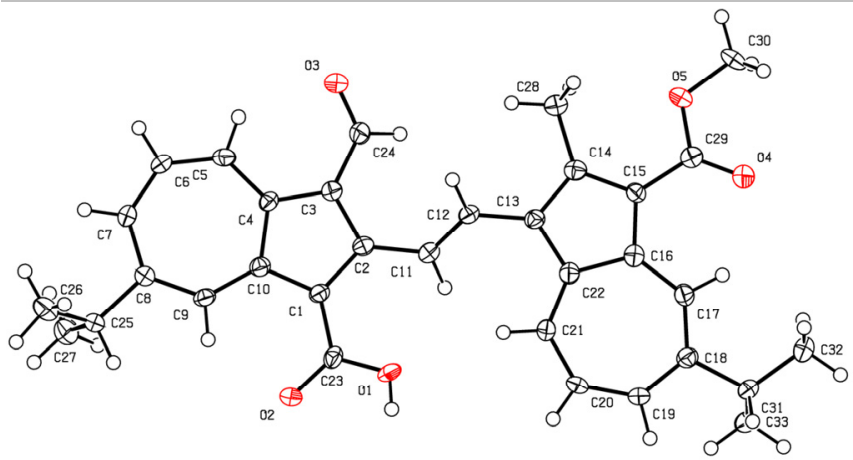

Figure 3. ORTEP Drawing of 23; Ellipsoids are drawn at $50 \%$ probability. $\mathrm{C} 2-\mathrm{C} 11$ 1.459(3) A, C12-C13 1.454(3) A, C14-C28 1.501(3) A.. ${ }^{[14]}$

Although the precursor 5 showed a weak absorption band at $\lambda_{\max }=489 \mathrm{~nm}$, the UV/Vis spectra of 23 in $\mathrm{CH}_{2} \mathrm{Cl}_{2}$ revealed a broad and strong absorption band in the visible region center at $\lambda_{\max }=476 \mathrm{~nm}$ (Figure 4). Since such absorption band cannot be observed in the UV/Vis spectrum of the precursor $\mathbf{5}$, the strong absorption band of $\mathbf{2 3}$ in the visible region might be originated from the intramolecular charge transfer (ICT) between the two azulene rings.

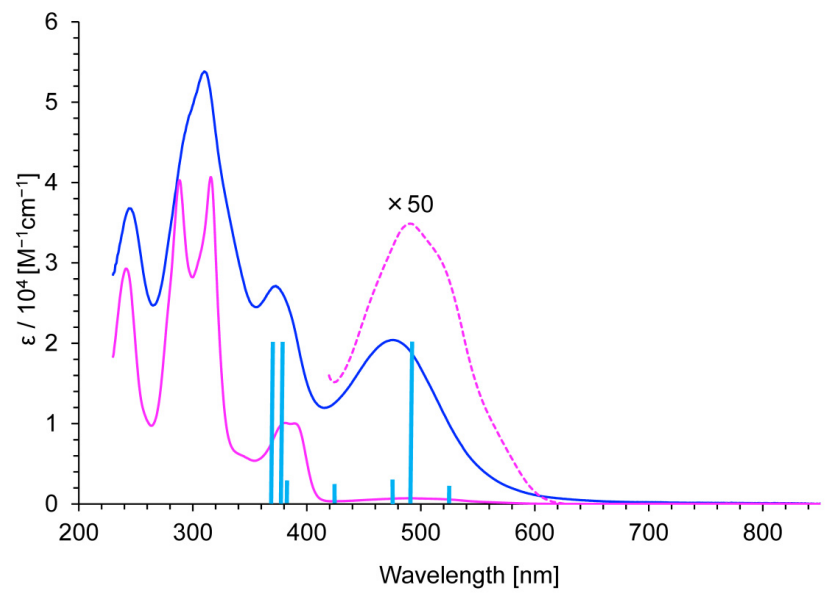

Figure 4. The UV/Vis spectra of 23 (blue line) and $\mathbf{5}$ (pink line) in $\mathrm{CH}_{2} \mathrm{Cl}_{2}$, and calculated spectrum of $\mathbf{2 3}$ (light-blue bar); the dotted line represents that of 50 magnifications.

In order to interpret these differences theoretically, orbital calculations of $\mathbf{5}$ and $\mathbf{2 3}$ were carried out by using timedependent density functional theory (TD-DFT) at B3LYP/6$31 \mathrm{G}^{* *}$ level (Table 2). The absorption band of 5 at $\lambda_{\max }=489 \mathrm{~nm}$ can be assigned to the transition originated from HOMO to LUMO. Thus, the longest wavelength absorption band of $\mathbf{5}$ should be attributed to the $\pi-\pi^{*}$ transition of the azulene ring itself (see Supporting Information, Figure S107). The calculations revealed that the strong absorption band of $\mathbf{2 3}$ in the visible region arises from the transition from HOMO to LUMO and LUMO+1 (Figure 5). However, the transition from HOMO to LUMO (ICT from 1-azulenyl group to 2-azulenyl moiety) has much more pronounced effect on the absorption band than that from HOMO to LUMO+1 $\left(\pi-\pi^{*}\right.$ transition of the 2-azulenyl moiety). The calculation also suggested the transition from 2azulenyl group to 1-azulenyl moiety (i.e., HOMO-1 $\rightarrow$ LUMO), but the contribution to the absorption band is lower than that from the former two transitions (from HOMO to LUMO and LUMO+1), since the oscillator strength of the transition is rather small. Although the $\pi-\pi^{*}$ transition of the 1-azulenyl group itself at $\lambda_{\max }=525 \mathrm{~nm}$ is shown by the calculation, this absorption band is probably overlapped with edge of the broad absorption band. Therefore, the results can be concluded that the strong and broad absorption band observed at $\lambda_{\max }=476 \mathrm{~nm}$ in the UV/Vis spectrum is ICT from the electron-rich 1-azulenyl group to the electron-deficient 2-azulenyl moiety as illustrated by the resonance structure in Scheme $1 .^{[15]}$

Table 1. Electronic transitions for $\mathbf{5}$ and $\mathbf{2 3}$ derived from the computed values based on the TD-DFT calculations at the B3LYP/6-31G** level and experimental results.

\begin{tabular}{llll}
\hline Compound & Experimental & \multicolumn{2}{c}{ Computed values } \\
\hline & $\lambda_{\max }(\log \varepsilon)$ & $\lambda_{\max }$ (strength) & $\begin{array}{l}\text { Composition of } \\
\text { (amplitude) }\end{array}$ \\
\hline $\mathbf{5}$ & $489(2.84)$ & $464(0.0059)$ & $\mathrm{H} \rightarrow \mathrm{b}(0.9665)$ \\
& $476(4.31)$ & $477(0.0273)$ & $\mathrm{H}-1 \rightarrow \mathrm{L}(0.8775)$ \\
& $493(0.4873)$ & $\mathrm{H} \rightarrow \mathrm{L}(0.9301)$ \\
& & $\mathrm{H} \rightarrow \mathrm{L}+1(0.2417)$ \\
& $525(0.0091)$ & $\mathrm{H} \rightarrow \mathrm{L}+1(0.9345)$ \\
\hline
\end{tabular}

[a] H = HOMO; L = LUMO
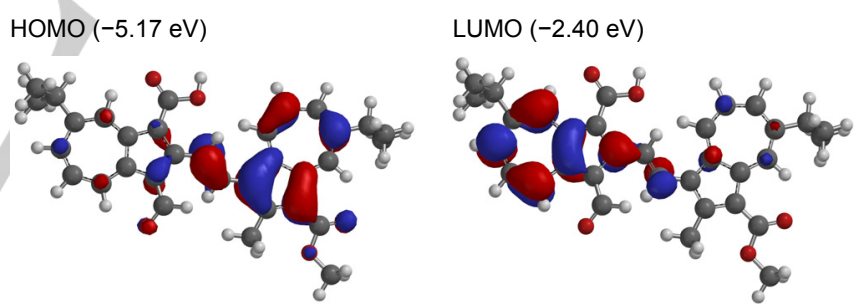

HOMO-1 (-5.80 eV)

LUMO+1 (-2.08 eV)
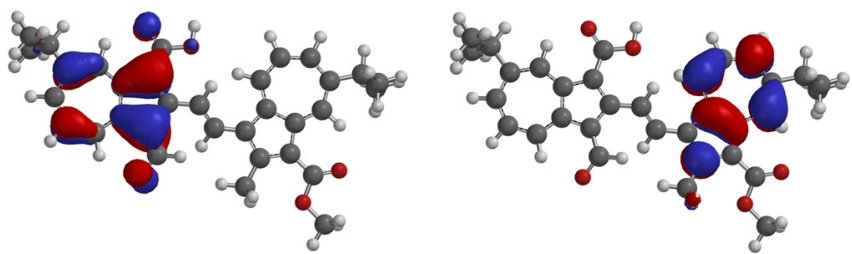

Figure 5. Frontier Kohn-Sham orbitals of 23 at the B3LYP/6-31G** level.

For the further development of 2-formylazulene synthesis, Vilsmeier formylation was also applied to 1,3-disubstituted azulenes. Although the preparation of 2-formylazulene derivatives by the Vilsmeier formylation of 1,3-dialkylazulenes was previously reported by Hafner and Moritz, yield of the products was relatively low because of the competition of the ipso-substitution at the alkyl substituent. ${ }^{5}$ We have also tried the formylation of 1,3,6-tri-tert-butylazulene by the same method, but 1-formylazulene derivative was exclusively obtained in excellent yield (98\%) by the ipso-substitution, instead of the 
formation of 2-formylazulene derivative. ${ }^{[16]}$ Therefore, methyl and phenyl groups were introduced to the 1,3-positions of azulene ring prior to the Vilsmeier reaction, since the secondary and tertiary alkyl groups could be replaced by the ipso-substitution (Scheme 2).

Precursors 24 and 25 were prepared by the reduction of ester function of methyl 3-phenylazulene-1-carboxylate derivatives $^{[17]}$ with DIBAL. Although the transformation from ester to methyl group by DIBAL reduction is usually difficult, compounds $\mathbf{2 4}$ and $\mathbf{2 5}$ were obtained from the corresponding precursors in excellent yields (24: $91 \%, \mathbf{2 5}$ : 93\%). Treatment of 24 with $\mathrm{POCl}_{3}$ in DMF afforded the corresponding 2formylazulene $\mathbf{2 6}$ in $27 \%$ yield, along with the recovery of $\mathbf{2 4}$ $(69 \%)$. The reaction showed almost the same yield as that of 1,3-dimethylazulene reported by Hafner et al. ${ }^{5}$ On the other hand, higher yield of the product $27(52 \%)$ was observed in the Vilsmeier formylation of 6-isopropylazulene derivative 25 . These results suggest that isopropyl group at the 6-position of azulene ring increases the reactivity at the 2-position toward the electrophilic substitution reaction, owing to the electron-donating inductive effect.
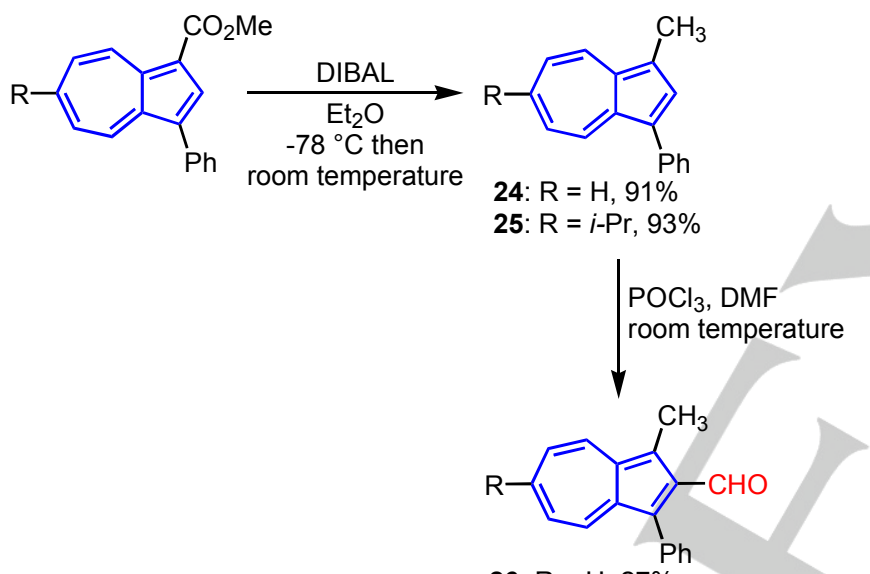

26: $\mathrm{R}=\mathrm{H}, 27 \%$

27: $\mathrm{R}=i-\operatorname{Pr}, 52 \%$

Scheme 2. Synthesis of 2-formylazulenes 26 and 27 by Vilsmeier reaction of 24 and 25.

Reactivity of 2-formylazulenes: 1-lodoazulene derivative $\mathbf{2 1}$ could not be obtained by the two-step transformation of 10 , but the iodination of 12 and 13 with $\mathrm{N}$-iodosuccinimide (NIS) afforded the corresponding 1-iodoazulenes 28 (90\%) and 21 $(99 \%)$ in excellent yields (Scheme 3 ). To test the reactivity toward the palladium-catalyzed coupling reaction, we have investigated the Suzuki-Miyaura and Sonogashira-Hagihara reactions by using 28 as a substrate. The Sonogashira-Hagihara reaction of $\mathbf{2 8}$ with ethynylbenzene in the presence of $\left[\mathrm{Pd}\left(\mathrm{PPh}_{3}\right)_{4}\right]$ catalyst gave the corresponding 1ethynylazulene $\mathbf{2 9}$ in $92 \%$ yield. The Suzuki-Miyaura coupling of 28 with phenylboronic acid in refluxing 1,4-dioxane also afforded the cross-coupled product $\mathbf{3 0}$ in $95 \%$ yield. Although preparations of 1-arylazulenes by the Suzuki-Miyaura coupling of 1 -haloazulenes ${ }^{[18]}$ or 1 -azulenyl triflates ${ }^{[19]}$ with arylbronic acids have been represented in the literatures, the reported yields of the products were relatively low. Although the efficient Suzuki-Miyaura coupling at the 1-position of azulene ring was reported by Oda et al, the procedure required expensive and electron-rich phosphine ligands (i.e., BINAP and dppf) for the successful reaction. ${ }^{[20]}$ The high yield of the product $\mathbf{3 0}$ was ascribed to the electron-withdrawing group at the 1- and 2positions of $\mathbf{2 8}$, which should increase the reactivity toward the oxidative addition of the palladium catalyst.

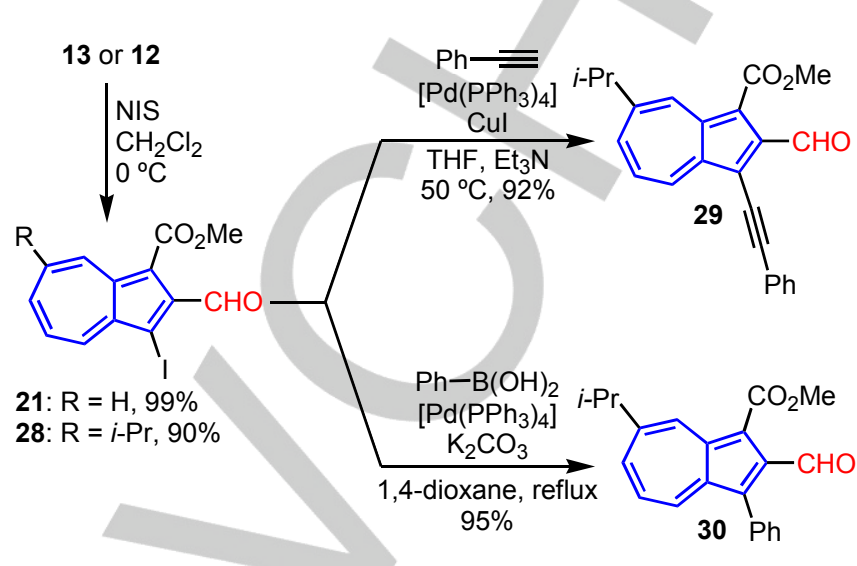

Scheme 3. Cross-coupling reactions of 1-iodoazulenes $\mathbf{2 1}$ and $\mathbf{2 8 .}$

2-Ethynylazulene derivatives are important building blocks for the construction of the extended $\pi$-electron systems. Usually, 2-ethynylazulenes have been prepared by Sonogashira-Hagihara reaction of 2-haloazulenes. ${ }^{[21]}$ However, preparation of the 2-haloazulene precursors is relatively difficult due to the tedious synthetic pathway as mentioned above. ${ }^{4 \mathrm{~d}}$ Even though we have previously reported the synthesis of 2ethynylazulene from 2-formylazulene via Corey-Fuchs reaction in moderate yield, the procedure required a four-step synthetic pathway. ${ }^{4 c}$ In this context development of facile and short step method is indispensable for establishing the practical synthesis of 2-ethynylazulene derivatives.

Seyferth-Gilbert reaction, which is a reaction of $\alpha$ diazophosphonate with aldehyde, is one of the efficient procedures to transform aldehyde to alkyne derivative in onestep. $^{[22]}$ Since the method requires a strong base, the $\alpha$ diazophosphonate derivatives such as Ohira-Bestmann reagent, whose reaction proceeds under milder basic conditions, has been developed. ${ }^{[23]}$ In 2008, Taber and co-workers have reported the modified Seyferth-Gilbert reaction with dimethyl 1diazo-2-oxo-2-phenylethylphosphonate (31). ${ }^{[2]}$ The reagent 31 is easy to prepare and has almost same reactivity compared to the Ohira-Bestmann reagent. However, there are no reports of this alkynylation reaction applied to the azulene derivatives, so far, in spite of the much promise of the reagent. For the development of novel synthetic route to 2-ethynylazulene derivatives, we adopted the modified Seyferth-Gilbert reaction to 2-formylazulenes under the similar conditions reported by Taber et al.

The yield and structure of 2-ethynylazulene derivatives obtained by the reaction are appeared in Table 3. The yield of 2ethynylazulene derivatives by the Seyferth-Gilbert reaction of 2formylazulenes was depended on the substituent on the sevenmembered ring. When the reaction was carried out with the substrates having isopropyl group on the seven-membered ring, the reaction afforded the 2-ethynylazulene derivatives $32(85 \%)$ and $37(80 \%)$ in good yields (entries 1 and 6). Meanwhile, 
absence of the isopropyl group on the seven-membered ring resulted in low to moderate yields of the products 33-36 (18-58\%), due to the competing decomposition reaction (entries 2-5). Alkynes 32-35 were relatively stable under the ambient conditions, but compounds $\mathbf{3 6}$ and $\mathbf{3 7}$ are readily decomposed even when stored at $-30^{\circ} \mathrm{C}$.

Table 3. Modified Seyferth-Gilbert reaction of 2-formylazulenes with 31 .<smiles>[R3]C1=Cc2c([R])c(C#C)c([R])c(c2[R])C=C1</smiles>

\begin{tabular}{llll}
\hline Entry & Substrate & Product & Yield [\%] $]^{\mathrm{a}}$ \\
\hline 1 & 12 & &
\end{tabular}
$13^{4 d}$<smiles>C#Cc1cc2cccccc-2c1C(C)=O</smiles>

33 18<smiles>C#Cc1c(F)c2cccccc-2c1C(C)=O</smiles><smiles>C#CC1=C/C(=C/C)C=C1C=C</smiles>

35 26<smiles>C#Cc1c(C)c2cccccc-2c1-c1ccccc1</smiles>
80<smiles>C#Cc1c(C)c2ccc(C(C)C)ccc-2c1-c1ccccc1</smiles>

[a] Two-step yield from 2-methylazulenes 1-9.

Presumed reaction mechanism of the Seyferth-Gilbert reaction is illustrated in Scheme 4 . In the case of the 2formylazulene derivatives without isopropyl group, anion intermediate generated from $\mathbf{3 1}$ might attack not only the formyl group but also electron-deficient seven-membered ring leading to the decomposition of the substrate (Path B). Whereas, the bulkiness of isopropyl group on 2-formylazulenes 32 and 37 might prevent the nucleophilic attack of the anion to the sevenmembered ring resulting to 2-ethynylazulenes in good yields (Path A).

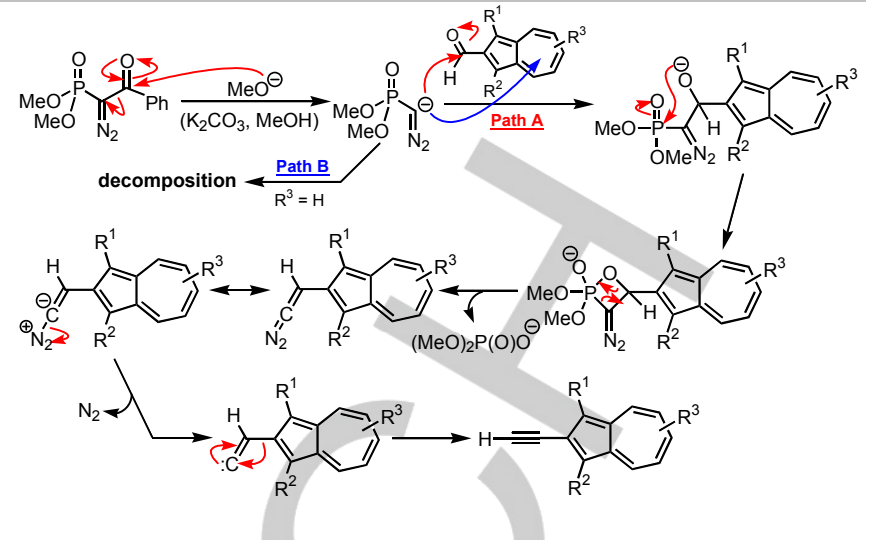

Scheme 4. Presumed reaction mechanism for the Seyferth-Gilbert reaction of 2-formylazulenes.

\section{Conclusions}

In conclusion, we have described the novel and effective synthetic procedure of 2-formyl- and 2-ethynylazulene derivatives from 2-methylazulenes, which are readily available by Yasunami-Takase's procedure.

The reaction of 2-methylazulenes with DMFDMA, followed by the oxidative cleavage of intermediately formed enamines with $\mathrm{NaIO}_{4}$ gave 2-formylazulenes in good to excellent yields, except for 2-methylazulene itself, and 1-bromo- and 1iodoazulene derivatives. As another synthetic method for 2formylazulenes, Vilsmeier reaction of 1-phenyl-3-methylazulenes was also examined. This study revealed that the isopropyl group at the seven-membered ring increased the reactivity toward the electrophilic reaction at the 2-position. Since the preparation of 2 -formylazulene and its derivatives is relatively difficult so far, our methods should become one of the efficient and practical procedures. In order to prepare further functionalized 2formylazulenes, palladium-catalyzed cross-coupling reaction of 28, which prepared by the reaction of 2-formylazulene 12 with NIS, was investigated. As a result, both Suzuki-Miyaura and Sonogashira-Hagihara reaction of $\mathbf{2 8}$ gave the corresponding cross-coupling products in excellent yields.

Furthermore, 2-formylazulenes could be transformed to 2ethynylazulenes 32-37 by modified Seyferth-Gilbert reaction with 1-diazo-2-oxo-2-phenylethylphosphonate (31). Although the yield of the products depends on the substituent on the azulene ring, this is the first example of the molecular transformation starting from 2-methylazulenes to 2-ethynylazulenes. Since the preparation of 2-formyl- and 2-ethynylazulene derivatives have difficult by the conventional methods, the results described in this paper should become one of the practical and effective methods for the synthesis of these derivatives.

\section{Experimental Section}

General: Melting points were determined with a Yanagimoto MPS3 micromelting apparatus. The HRMS data were obtained with a Bruker Daltonics APEX III instrument or a JEOL JMS-700 instrument. The IR and UV/Vis spectra were recorded with JASCO FTIR-4100 and Shimadzu UV-2550 spectrophotometers. The ${ }^{1} \mathrm{H}$ and ${ }^{13} \mathrm{C}$ NMR spectra were recorded with a JEOL ECA500 spectrometer at 500 and $125 \mathrm{MHz}$, respectively. 
Methyl 3-formyl-7-isopropyl-2-methylazulene-1-carboxylate (5): $\mathrm{POCl}_{3}(4.61 \mathrm{~g}, 30.1 \mathrm{mmol})$ was added at $0{ }^{\circ} \mathrm{C}$ to a solution of $1(2.44 \mathrm{~g}, 10.1 \mathrm{mmol})$ in DMF $(100 \mathrm{~mL})$. The resulting mixture was stirred at room temperature for $3 \mathrm{~h}$. The reaction mixture was poured into aq. $\mathrm{K}_{2} \mathrm{CO}_{3}$ and extracted with toluene. The organic layer was washed with brine, dried with $\mathrm{Na}_{2} \mathrm{SO}_{4}$, and concentrated under reduced pressure. The crude product was purified by recrystallization from $\mathrm{CH}_{2} \mathrm{Cl}_{2} /$ hexane to give $5(2.53 \mathrm{~g}$ $93 \%$ ) as purple crystals. M.p. $149.5-150{ }^{\circ} \mathrm{C}$; IR (ATR): $\mathrm{V}_{\max }=$ 2960 (w), 2927 (w), 2869 (w), 2731 (w), 1686 (s), 1647 (s), 1601 (w), $1574(w), 1522(w), 1506(w), 1470(m), 1439(s), 1407(w)$, $1382(w), 1374(w), 1342(w), 1280(w), 1230(m), 1200(m)$, $1135(w), 1110(\mathrm{~m}), 1090(\mathrm{~m}), 1071(\mathrm{w}), 1047(\mathrm{w}), 991(\mathrm{w}), 960$ $(w), 930(w), 874(w), 807(w), 794(w), 783(m), 666(m) \mathrm{cm}^{-1}$; ${ }^{1} \mathrm{H}$ NMR $\left(500 \mathrm{MHz}, \mathrm{CDCl}_{3}\right): \delta_{\mathrm{H}}=10.53(\mathrm{~s}, 1 \mathrm{H}, \mathrm{CHO}), 9.73(\mathrm{~d}, 1 \mathrm{H}$, $\left.J=1.4 \mathrm{~Hz}, \mathrm{H}_{8}\right), 9.68\left(\mathrm{~d}, 1 \mathrm{H}, J=9.7 \mathrm{~Hz}, \mathrm{H}_{4}\right), 7.88(\mathrm{~d}, 1 \mathrm{H}, J=$ $10.3 \mathrm{~Hz}, \mathrm{H}_{6}$ ), 7.75 (t, $\left.1 \mathrm{H}, J=10.0 \mathrm{~Hz}, \mathrm{H}_{5}\right), 4.00$ (s, 3H, $\left.\mathrm{CO}_{2} \mathrm{Me}\right)$, 3.26 (sept, $1 \mathrm{H}, J=6.9 \mathrm{~Hz}, i-\mathrm{Pr}$ ), 3.03 (s, 3H, Me), 1.43 (d, 6H, J $=6.9 \mathrm{~Hz}, i-\mathrm{Pr}) \mathrm{ppm} ;{ }^{13} \mathrm{C}$ NMR $\left(125 \mathrm{MHz}, \mathrm{CDCl}_{3}\right): \delta_{\mathrm{C}}=186.7$, $166.5,158.7,154.2,145.1,143.5,139.5,137.8,136.1,132.8$, 121.7, 115.8, 51.3, 39.6, 24.7, 14.5 ppm; HRMS (MALDI-TOF): calcd for $\mathrm{C}_{17} \mathrm{H}_{18} \mathrm{O}_{3}+\mathrm{H}^{+}[\mathrm{M}+\mathrm{H}]^{+}$271.1329; found: 271.1334 .

1,3-diformyl-2-methylazulene (6): $\mathrm{POCl}_{3}(4.60 \mathrm{~g}, 30.0 \mathrm{mmol})$ was added at $0{ }^{\circ} \mathrm{C}$ to a solution of $11(1.42 \mathrm{~g}, 10.0 \mathrm{mmol})$ in DMF $(50 \mathrm{~mL})$. The resulting mixture was stirred at $100{ }^{\circ} \mathrm{C}$ for 12 $\mathrm{h}$. The reaction mixture was poured into aq. $\mathrm{K}_{2} \mathrm{CO}_{3}$ and extracted with AcOEt. The organic layer was washed with brine, dried with $\mathrm{Na}_{2} \mathrm{SO}_{4}$, and concentrated under reduced pressure. The residue was purified by column chromatography on silica gel with toluene/AcOEt $(10: 1)$ to give $6(1.76 \mathrm{~g}, 8.90 \mathrm{mmol}$, $89 \%)$ as red needles. M.p. $194-195{ }^{\circ} \mathrm{C}$; IR (ATR): $\mathrm{V}_{\max }=2782$ $(w), 2751(w), 1632(s), 1594(w), 1537(w), 1508(m), 1457(m)$, $1435(\mathrm{~s}), 1399(\mathrm{~m}), 1375(\mathrm{~m}), 1322(\mathrm{w}), 1292(\mathrm{~m}), 1138(\mathrm{w})$, $1092(w), 1035(w), 978(s), 917(m), 873(w), 744(s), 707(w)$, $681(\mathrm{w}), 654(\mathrm{~s}) \mathrm{cm}^{-1} ;{ }^{1} \mathrm{H}$ NMR $\left(500 \mathrm{MHz}, \mathrm{CDCl}_{3}\right): \delta_{\mathrm{H}}=10.53(\mathrm{~s}$, $2 \mathrm{H}, \mathrm{CHO}$ ), 9.75 (d, $\left.2 \mathrm{H}, J=9.8 \mathrm{~Hz}, \mathrm{H}_{4,8}\right), 8.00(\mathrm{t}, 1 \mathrm{H}, J=9.8 \mathrm{~Hz}$, $\mathrm{H}_{6}$ ), $7.87\left(\mathrm{t}, 2 \mathrm{H}, J=9.8 \mathrm{~Hz}, \mathrm{H}_{5,7}\right), 3.06$ (s, 3H, Me) ppm; ${ }^{13} \mathrm{C}$ $\operatorname{NMR}\left(125 \mathrm{MHz}, \mathrm{CDCl}_{3}\right): \delta_{\mathrm{C}}=186.4,159.8,144.6,141.1,138.4$, 134.3, 122.6, 74.2, 11.9 ppm; HRMS (MALDI-TOF): calcd for $\mathrm{C}_{13} \mathrm{H}_{10} \mathrm{O}_{2}+\mathrm{H}^{+}[\mathrm{M}+\mathrm{H}]^{+}$199.0754; found: 199.0736 .

Methyl 3-chloro-2-methylazulene-1-carboxylate (8): To a solution of $2(407 \mathrm{mg}, 2.03 \mathrm{mmol})$ in $\mathrm{CHCl}_{3}(10 \mathrm{~mL})$ and $\mathrm{Et}_{3} \mathrm{~N}(1$ $\mathrm{mL}$ ) was added $\mathrm{N}$-chlorosuccinimide $(549 \mathrm{mg}, 4.11 \mathrm{mmol})$ at room temperature. The resulting mixture was stirred at the same temperature for $2 \mathrm{~h}$ under an $\mathrm{Ar}$ atmosphere. The reaction mixture was poured into a sat. $\mathrm{Na}_{2} \mathrm{SO}_{3}$ solution and extracted with $\mathrm{CHCl}_{3}$. The organic layer was washed with brine, dried with $\mathrm{Na}_{2} \mathrm{SO}_{4}$, and concentrated under reduced pressure. The crude product was purified by column chromatography on silica gel with $\mathrm{CH}_{2} \mathrm{Cl}_{2}$ to give 8 (399 $\left.\mathrm{mg}, 84 \%\right)$ as green solid. m.p. 93-95 ${ }^{\circ} \mathrm{C}$; IR (AT-R) $v_{\max }=2947(\mathrm{w}), 2829(\mathrm{w}), 1678(\mathrm{~s}), 1581$ $(w), 1534(w), 1497(w), 1453(m), 1436(m), 1410(s), 1381(w)$, $1359(\mathrm{w}), 1289(\mathrm{w}), 1241(\mathrm{~m}), 1213(\mathrm{~s}), 1149(\mathrm{w}), 1116(\mathrm{~s}), 1083$ (s), $1071(\mathrm{~s}), 1047(\mathrm{~s}), 1014(\mathrm{w}), 971(\mathrm{w}), 924(\mathrm{w}), 902(\mathrm{w}), 876$ $(w), 844(w), 782(m), 741(m), 718(w), 693(w), 656(w) \mathrm{cm}^{-1}$; ${ }^{1} \mathrm{H}$ NMR $\left(500 \mathrm{MHz}, \mathrm{CDCl}_{3}\right): \delta_{\mathrm{H}}=9.49\left(\mathrm{~d}, 1 \mathrm{H}, J=9.9 \mathrm{~Hz}, \mathrm{H}_{8}\right)$, $8.45\left(\mathrm{~d}, 1 \mathrm{H}, J=9.9 \mathrm{~Hz}, \mathrm{H}_{4}\right), 7.74\left(\mathrm{t}, 1 \mathrm{H}, J=9.9 \mathrm{~Hz}, \mathrm{H}_{6}\right), 7.53-$ 7.45 (m, $\left.2 \mathrm{H}, \mathrm{H}_{5,7}\right), 3.98$ (s, $3 \mathrm{H}, \mathrm{CO}_{2} \mathrm{Me}$ ), 2.83 (s, 3H, Me) ppm;
${ }^{13} \mathrm{C}$ NMR $\left(125 \mathrm{MHz}, \mathrm{CDCl}_{3}\right): \delta_{\mathrm{C}}=166.0,149.4,139.8,138.6$, 137.0, 136.7, 133.9, 128.2, 127.1, 118.4, 113.6, 51.2, 15.4 ppm; HRMS (El-MS, positive): calcd for $\mathrm{C}_{13} \mathrm{H}_{11} \mathrm{ClO}_{2}{ }^{+}[\mathrm{M}]^{+} 234.0443$; found: 234.0442 .

Methyl 1-bromo-2-methylazulene-3-carboxylate (9): To a solution of $2(411 \mathrm{mg}, 2.05 \mathrm{mmol})$ in $\mathrm{CHCl}_{3}(10 \mathrm{~mL})$ and $\mathrm{Et}_{3} \mathrm{~N}(1$ $\mathrm{mL}$ ) was added $\mathrm{N}$-bromosuccinimide $(743 \mathrm{mg}, 4.17 \mathrm{mmol})$ at room temperature. The resulting mixture was stirred at the same temperature for $1 \mathrm{~h}$ under an $\mathrm{Ar}$ atmosphere. The reaction mixture was poured into a sat. $\mathrm{Na}_{2} \mathrm{SO}_{3}$ solution and extracted with $\mathrm{CHCl}_{3}$. The organic layer was washed with brine, dried with $\mathrm{Na}_{2} \mathrm{SO}_{4}$, and concentrated under reduced pressure. The crude product was purified by column chromatography on silica gel with $\mathrm{CH}_{2} \mathrm{Cl}_{2}$ to give 9 (366 mg, 64\%) as green solid. m.p. 92-93 ${ }^{\circ} \mathrm{C}$; IR (AT-R) $\mathrm{v}_{\max }=3006$ (w), 2957 (w), 2918 (w), 1691 (s), $1593(w), 1581(w), 1540(w), 1499(w), 1460(m), 1433(s)$, $1411(\mathrm{~m}), 1393(\mathrm{~m}), 1364(\mathrm{~m}), 1297(\mathrm{w}), 1232(\mathrm{~m}), 1202(\mathrm{~s})$, $1076(\mathrm{~s}), 1017(\mathrm{w}), 1007(\mathrm{w}), 953(\mathrm{w}), 834(\mathrm{w}), 778(\mathrm{~m}), 739(\mathrm{~m})$, $655(\mathrm{w}) \mathrm{cm}^{-1} ;{ }^{1} \mathrm{H}$ NMR $\left(500 \mathrm{MHz}, \mathrm{CDCl}_{3}\right): \delta_{\mathrm{H}}=9.48(\mathrm{~d}, 1 \mathrm{H}, \mathrm{J}=$ $\left.9.9 \mathrm{~Hz}, \mathrm{H}_{4}\right), 8.45\left(\mathrm{~d}, 1 \mathrm{H}, \mathrm{J}=9.9 \mathrm{~Hz}, \mathrm{H}_{8}\right), 7.75(\mathrm{t}, 1 \mathrm{H}, J=9.9 \mathrm{~Hz}$, $\left.\mathrm{H}_{6}\right)$, 7.55-7.49 (m, 2H, $\left.\mathrm{H}_{5,7}\right), 3.98\left(\mathrm{~s}, 3 \mathrm{H}, \mathrm{CO}_{2} \mathrm{Me}\right), 2.85(\mathrm{~s}, 3 \mathrm{H}$, $\mathrm{Me}) \mathrm{ppm} ;{ }^{13} \mathrm{C}$ NMR $\left(125 \mathrm{MHz}, \mathrm{CDCl}_{3}\right): \delta_{\mathrm{C}}=166.0,151.4,140.9$, $138.8,138.5,136.5,135.7,128.3,127.4,114.7,108.7,51.2$, 17.2 ppm; HRMS (El-MS, positive): calcd for $\mathrm{C}_{13} \mathrm{H}_{11} \mathrm{BrO}_{2}{ }^{+}[\mathrm{M}]^{+}$ 277.9937; found: 277.9934 .

Methyl 2-formyl-7-isopropylazulene-1-carboxylate (12): DMFDMA (3.57 g, $30.0 \mathrm{mmol})$ was added to a solution of 1 (2.43 $\mathrm{g}, 10.0 \mathrm{mmol})$ in DMF $(7 \mathrm{~mL})$. The resulting mixture was refluxed for $20 \mathrm{~h}$. The reaction mixture was poured into water and extracted with hexane/AcOEt. The organic layer was washed with brine, dried with $\mathrm{Na}_{2} \mathrm{SO}_{4}$, and concentrated under reduced pressure to give crude enamine product as dark brown oil. To this crude enamine product $(2.83 \mathrm{~g})$ in a mixed solvent of THF $(25 \mathrm{~mL})$ and $\mathrm{H}_{2} \mathrm{O}(25 \mathrm{~mL})$ was added sodium periodate $(6.12 \mathrm{~g}$, $28.6 \mathrm{mmol}$ ) and the mixture was stirred at room temperature for 1 day. After the reaction mixture was filtered, the filtrate was extracted with $\mathrm{CH}_{2} \mathrm{Cl}_{2}$. The organic layer was dried over $\mathrm{Na}_{2} \mathrm{SO}_{4}$ and the solvent was removed under reduced pressure. The residue was purified by column chromatography on silica gel with $\mathrm{CH}_{2} \mathrm{Cl}_{2}$ to give $12(1.39 \mathrm{~g}, 54 \%)$ as green solid. M.p. 94-95 ${ }^{\circ} \mathrm{C}$; IR (ATR): $v_{\max }=3104(w), 2954(w), 2885(w), 1678$ (s), $1666(\mathrm{~s}), 1578(\mathrm{w}), 1468(\mathrm{~m}), 1442(\mathrm{~m}), 1420(\mathrm{~m}), 1389(\mathrm{w})$, $1362(w), 1349(m), 1332(w), 1313(w), 1263(w), 1230(s)$, $1192(m), 1178(w), 1143(w), 1132(w), 1068(m), 1050(w)$, $1024(\mathrm{~m}), 978(\mathrm{w}), 955(\mathrm{w}), 936(\mathrm{w}), 875(\mathrm{w}), 849(\mathrm{~m}), 799(\mathrm{~m})$, $779(\mathrm{~m}), 730(\mathrm{w}), 678(\mathrm{w}), 655(\mathrm{w}) \mathrm{cm}^{-1} ;{ }^{1} \mathrm{H}$ NMR $(500 \mathrm{MHz}$, $\left.\mathrm{CDCl}_{3}\right): \delta_{\mathrm{H}}=10.93(\mathrm{~s}, 1 \mathrm{H}, \mathrm{CHO}), 9.86\left(\mathrm{~d}, 1 \mathrm{H}, J=1.1 \mathrm{~Hz}, \mathrm{H}_{8}\right)$, $8.48\left(\mathrm{~d}, 1 \mathrm{H}, J=9.7 \mathrm{~Hz}, \mathrm{H}_{4}\right), 7.86\left(\mathrm{~d}, 1 \mathrm{H}, J=10.3 \mathrm{~Hz}, \mathrm{H}_{6}\right), 7.67$ (s, $\left.1 \mathrm{H}, \mathrm{H}_{3}\right), 7.45$ (t, $\left.1 \mathrm{H}, J=9.9 \mathrm{~Hz}, \mathrm{H}_{5}\right), 4.03\left(\mathrm{~s}, 3 \mathrm{H}, \mathrm{CO}_{2} \mathrm{Me}\right)$, 3.23 (sept, $1 \mathrm{H}, J=6.9 \mathrm{~Hz}, i-\mathrm{Pr}$ ), $1.43(\mathrm{~d}, 6 \mathrm{H}, J=6.9 \mathrm{~Hz}, i-\mathrm{Pr}$ ) ppm; ${ }^{13} \mathrm{C}$ NMR $\left(125 \mathrm{MHz}, \mathrm{CDCl}_{3}\right): \delta_{\mathrm{C}}=192.7,165.5,150.1$, $145.1,142.4,142.2,141.6,141.2,127.6,117.4,114.3,51.5$, $39.3,24.7 \mathrm{ppm}$, one signal is overlapped with the other; HRMS (MALDI-TOF): calcd for $\mathrm{C}_{16} \mathrm{H}_{16} \mathrm{O}_{3}+\mathrm{Ag}^{+}[\mathrm{M}+\mathrm{Ag}]^{+} 363.0145$; found: 363.0122 .

Methyl 2-formylazulene-1-carboxylate (13): DMFDMA (359 $\mathrm{mg}, 3.01 \mathrm{mmol})$ was added to a solution of $2(203 \mathrm{mg}, 1.01$ $\mathrm{mmol})$ in DMF $(2 \mathrm{~mL})$. The resulting mixture was refluxed for 38 
h. The reaction mixture was poured into water and extracted with hexane/AcOEt. The organic layer was washed with brine, dried with $\mathrm{Na}_{2} \mathrm{SO}_{4}$, and concentrated under reduced pressure to give crude enamine product as dark red oil. To this crude enamine product $(258 \mathrm{mg})$ in a mixed solvent of THF $(5 \mathrm{~mL})$ and $\mathrm{H}_{2} \mathrm{O}(5 \mathrm{~mL})$ was added sodium periodate $(647 \mathrm{mg}, 3.02 \mathrm{mmol})$ and the mixture was stirred at room temperature for 1 day. After the reaction mixture was filtered, the filtrate was extracted with $\mathrm{CH}_{2} \mathrm{Cl}_{2}$. The organic layer was dried over $\mathrm{Na}_{2} \mathrm{SO}_{4}$ and the solvent was removed under reduced pressure. The residue was purified by column chromatography on silica gel with $\mathrm{CH}_{2} \mathrm{Cl}_{2}$ to give $13(145 \mathrm{mg}, 67 \%)$ as green solid. M.p. $110-111{ }^{\circ} \mathrm{C}$ (lit. $\left.119-120{ }^{\circ} \mathrm{C}\right) ;{ }^{6}{ }^{1} \mathrm{H}$ NMR $\left(500 \mathrm{MHz}, \mathrm{CDCl}_{3}\right): \delta_{\mathrm{H}}=10.94(\mathrm{~s}, 1 \mathrm{H}$, $\mathrm{CHO}$ ), $9.74\left(\mathrm{~d}, 1 \mathrm{H}, J=10.0 \mathrm{~Hz}, \mathrm{H}_{8}\right), 8.58\left(\mathrm{~d}, 1 \mathrm{H}, J=9.5 \mathrm{~Hz}, \mathrm{H}_{4}\right)$, $7.91\left(\mathrm{t}, 1 \mathrm{H}, J=9.7 \mathrm{~Hz}, \mathrm{H}_{6}\right), 7.76\left(\mathrm{~s}, 1 \mathrm{H}, \mathrm{H}_{3}\right), 7.59(\mathrm{t}, 1 \mathrm{H}, J=10.0$ $\left.\mathrm{Hz}, \mathrm{H}_{7}\right), 7.49\left(\mathrm{t}, 1 \mathrm{H}, J=9.7 \mathrm{~Hz}, \mathrm{H}_{5}\right), 4.03\left(\mathrm{~s}, 3 \mathrm{H}, \mathrm{CO}_{2} \mathrm{Me}\right) \mathrm{ppm}$; Data are in agreement with those previously reported in reference 6 .

Dimethyl 2-formylazulene-1,3-dicarboxylate (14): DMFDMA (267 mg, $2.24 \mathrm{mmol})$ was added to a solution of 3 (259 mg, 1.00 $\mathrm{mmol})$ in DMF (1.5 mL). The resulting mixture was refluxed for 4 $h$. The reaction mixture was poured into water and extracted with hexane/AcOEt. The organic layer was washed with brine, dried with $\mathrm{Na}_{2} \mathrm{SO}_{4}$, and concentrated under reduced pressure to give crude enamine product as dark red solid. To this crude enamine product $(313 \mathrm{mg})$ in a mixed solvent of THF $(5 \mathrm{~mL})$ and $\mathrm{H}_{2} \mathrm{O}(5 \mathrm{~mL})$ was added sodium periodate $(647 \mathrm{mg}, 3.02 \mathrm{mmol})$ and the mixture was stirred at room temperature for $16 \mathrm{~h}$. After the reaction mixture was filtered, the filtrate was extracted with $\mathrm{CH}_{2} \mathrm{Cl}_{2}$. The organic layer was dried over $\mathrm{Na}_{2} \mathrm{SO}_{4}$ and the solvent was removed under reduced pressure. The residue was purified by column chromatography on silica gel with $\mathrm{CH}_{2} \mathrm{Cl}_{2}$ to give 14 (166 mg, 61\%) as red solid. M.p. $170-171{ }^{\circ} \mathrm{C}$; (lit. 167-168 $\left.{ }^{\circ} \mathrm{C}\right) ;{ }^{6}$ IR (ATR): $v_{\max }=3004(\mathrm{w}), 2957(\mathrm{w}), 1694(\mathrm{~s})$, $1537(w), 1490(w), 1455(m), 1442(s), 1434(\mathrm{~s}), 1421(\mathrm{~m})$, $1395(\mathrm{~m}), 1300(\mathrm{w}), 1243(\mathrm{~m}), 1209(\mathrm{~s}), 1174(\mathrm{~s}), 1084(\mathrm{~s}), 1065$ $(\mathrm{m}), 1012(\mathrm{w}), 992(\mathrm{w}), 951(\mathrm{w}), 895(\mathrm{w}), 800(\mathrm{~m}), 779(\mathrm{w}), 743$ $(\mathrm{m}), 680(\mathrm{w}), 661(\mathrm{w}) \mathrm{cm}^{-1} ;{ }^{1} \mathrm{H}$ NMR $\left(500 \mathrm{MHz}, \mathrm{CDCl}_{3}\right): \delta_{\mathrm{H}}=$ $10.80(\mathrm{~s}, 1 \mathrm{H}, \mathrm{CHO}), 9.76\left(\mathrm{~d}, 2 \mathrm{H}, J=10.0 \mathrm{~Hz}, \mathrm{H}_{4,8}\right), 8.07(\mathrm{t}, 1 \mathrm{H}, J$ $\left.=9.9 \mathrm{~Hz}, \mathrm{H}_{6}\right), 7.83\left(\mathrm{t}, 2 \mathrm{H}, J=10.0 \mathrm{~Hz}, \mathrm{H}_{5,7}\right), 3.95(\mathrm{~s}, 6 \mathrm{H}$, $\mathrm{CO}_{2} \mathrm{Me}$ ) ppm. Data are in agreement with those previously reported in reference 6 .

Methyl 2,3-diformylazulene-1-carboxylate (15): DMFDMA (490 mg, $4.11 \mathrm{mmol}$ ) was added to a solution of 4 (456 mg, 2.00 $\mathrm{mmol})$ in DMF (4 mL). The resulting mixture was refluxed for $4 \mathrm{~h}$. The reaction mixture was poured into water and extracted with $\mathrm{CH}_{2} \mathrm{Cl}_{2}$. The organic layer was washed with brine, dried with $\mathrm{Na}_{2} \mathrm{SO}_{4}$, and concentrated under reduced pressure to give crude enamine product as dark red solid. To this crude enamine product $(567 \mathrm{mg})$ in a mixed solvent of THF $(8 \mathrm{~mL})$ and $\mathrm{H}_{2} \mathrm{O}(8$ $\mathrm{mL}$ ) was added sodium periodate $(1.28 \mathrm{~g}, 6.00 \mathrm{mmol})$ to and the mixture was stirred at room temperature for $3 \mathrm{~h}$. After the reaction mixture was filtered, the filtrate was extracted with $\mathrm{CH}_{2} \mathrm{Cl}_{2}$. The organic layer was dried over $\mathrm{Na}_{2} \mathrm{SO}_{4}$ and the solvent was removed under reduced pressure. The residue was purified by column chromatography on silica gel with toluene/AcOEt $(5: 1)$ to give $15(400 \mathrm{mg}, 83 \%)$ as purple solid. M.p. $163-164{ }^{\circ} \mathrm{C}$; IR (ATR): $v_{\max }=2964(\mathrm{w}), 2874(\mathrm{w}), 1701(\mathrm{~m})$, $1685(\mathrm{~m}), 1662$ (s), $1579(\mathrm{w}), 1531(\mathrm{w}), 1497(\mathrm{w}), 1457(\mathrm{~s}), 1425$ (s), $1389(\mathrm{~m}), 1317(\mathrm{w}), 1297(\mathrm{w}), 1239(\mathrm{~m}), 1212(\mathrm{~s}), 1194(\mathrm{~m})$, $1157(w), 1119(\mathrm{~s}), 1067(\mathrm{~m}), 997(\mathrm{w}), 987(\mathrm{~m}), 930(\mathrm{~m}), 892(\mathrm{w})$, $874(w), 805(w), 785(w), 761(w), 746(w), 725(w), 700(w)$, $665(\mathrm{w}) \mathrm{cm}^{-1} ;{ }^{1} \mathrm{H}$ NMR $\left(500 \mathrm{MHz}, \mathrm{CDCl}_{3}\right): \delta_{\mathrm{H}}=10.98(\mathrm{~s}, 1 \mathrm{H}$, $\mathrm{CHO}$ ), 10.55 (s, 1H, CHO), $10.10\left(\mathrm{~d}, 1 \mathrm{H}, J=10.0 \mathrm{~Hz}, \mathrm{H}_{8}\right), 9.88$ $\left(\mathrm{d}, 1 \mathrm{H}, J=10.0 \mathrm{~Hz}, \mathrm{H}_{4}\right), 8.16\left(\mathrm{t}, 1 \mathrm{H}, J=9.7 \mathrm{~Hz}, \mathrm{H}_{6}\right), 7.93-7.89$ $\left(\mathrm{m}, 2 \mathrm{H}, \mathrm{H}_{5,7}\right), 4.05$ (s, 3H, $\left.\mathrm{CO}_{2} \mathrm{Me}\right) \mathrm{ppm} ;{ }^{13} \mathrm{C}$ NMR $(125 \mathrm{MHz}$, $\left.\mathrm{CDCl}_{3}\right): \delta_{\mathrm{C}}=192.9,189.2,164.7,148.7,144.1,143.8,143.7$, $142.9,142.2,133.5,132.4,122.9,117.4,52.3$ ppm; HRMS (MALDI-TOF): calcd for $\mathrm{C}_{14} \mathrm{H}_{10} \mathrm{O}_{4}+\mathrm{Ag}^{+}\left[\mathrm{M}+\mathrm{Ag}^{+} 348.9625\right.$; found: 348.9663 .

Methyl 2,3-diformyl-7-isopropylazulene-1-carboxylate (16): DMFDMA (1.53 g, $12.8 \mathrm{mmol})$ was added to a solution of 5 (2.47 $\mathrm{g}, 9.15 \mathrm{mmol})$ in DMF $(15 \mathrm{~mL})$. The resulting mixture was refluxed for $4 \mathrm{~h}$. The reaction mixture was poured into water and extracted with $\mathrm{CH}_{2} \mathrm{Cl}_{2}$. The organic layer was washed with brine, dried with $\mathrm{Na}_{2} \mathrm{SO}_{4}$, and concentrated under reduced pressure to give crude enamine product as dark red solid. To this crude enamine product $(2.91 \mathrm{~g})$ in a mixed solvent of THF $(22 \mathrm{~mL})$ and $\mathrm{H}_{2} \mathrm{O}(22 \mathrm{~mL})$ was added sodium periodate $(5.77 \mathrm{~g}, 27.0 \mathrm{mmol})$ and the mixture was stirred at room temperature for $3 \mathrm{~h}$. After the reaction mixture was filtered, the filtrate was extracted with $\mathrm{CH}_{2} \mathrm{Cl}_{2}$. The organic layer was dried over $\mathrm{Na}_{2} \mathrm{SO}_{4}$ and the solvent was removed under reduced pressure. The residue was purified by column chromatography on silica gel with $\mathrm{CH}_{2} \mathrm{Cl}_{2}$ to give $16(2.16 \mathrm{~g}, 85 \%)$ as dark purple solid. M.p. $207-208^{\circ} \mathrm{C}$; IR (ATR): $v_{\max }=2965(w), 2872(w), 1752(w), 1682(s), 1650(s)$, $1573(\mathrm{w}), 1494(\mathrm{~m}), 1465(\mathrm{~m}), 1440$ (s), $1421(\mathrm{~m}), 1404(\mathrm{~m})$, $1382(\mathrm{~m}), 1341(\mathrm{w}), 1316(\mathrm{w}), 1284(\mathrm{w}), 1229(\mathrm{~s}), 1211(\mathrm{~m})$, $1136(\mathrm{~m}), 1117(\mathrm{~m}), 1093(\mathrm{~m}), 1067(\mathrm{w}), 1048(\mathrm{w}), 1005(\mathrm{~m})$, $984(\mathrm{~m}), 933(\mathrm{~m}), 893(\mathrm{w}), 818(\mathrm{~m}), 782(\mathrm{~m}), 730(\mathrm{w}), 695(\mathrm{w})$, $662(\mathrm{~m}) \mathrm{cm}^{-1} ;{ }^{1} \mathrm{H}$ NMR $\left(500 \mathrm{MHz}, \mathrm{CDCl}_{3}\right): \delta_{\mathrm{H}}=10.95(\mathrm{~s}, 1 \mathrm{H}$, $\mathrm{CHO}), 10.49$ (s, 1H, CHO), 9.99-9.96 (m, 2H, $\left.\mathrm{H}_{4,8}\right), 8.10$ (d, $1 \mathrm{H}$, $\left.J=10.2 \mathrm{~Hz}, \mathrm{H}_{6}\right), 7.86\left(\mathrm{t}, 1 \mathrm{H}, J=10.2 \mathrm{~Hz}, \mathrm{H}_{5}\right), 4.04(\mathrm{~s}, 3 \mathrm{H}$, $\mathrm{CO}_{2} \mathrm{Me}$ ), 3.32 (sept, $\left.1 \mathrm{H}, J=6.9 \mathrm{~Hz}, i-\mathrm{Pr}\right), 1.46(\mathrm{~d}, 6 \mathrm{H}, J=6.9 \mathrm{~Hz}$, i-Pr) ppm; ${ }^{13} \mathrm{C}$ NMR $\left(125 \mathrm{MHz}, \mathrm{CDCl}_{3}\right): \delta_{\mathrm{C}}=193.1,188.9,164.9$, $154.7,149.0,143.8,143.5,142.3,142.2,142.0,133.3,122.1$, 116.2, 52.1, 39.5, 24.6 ppm; HRMS (MALDI-TOF): calcd for $\mathrm{C}_{17} \mathrm{H}_{16} \mathrm{O}_{4}+\mathrm{Ag}^{+}[\mathrm{M}+\mathrm{Ag}]^{+}$391.0094; found: 391.0093 .

Enamine intermediate: M.p. $91-93{ }^{\circ} \mathrm{C}$; IR (ATR): $\mathrm{v}_{\max }=2963$ $(\mathrm{w}), 1673(\mathrm{~m}), 1624(\mathrm{~s}), 1610(\mathrm{~s}), 1599(\mathrm{~s}), 1566(\mathrm{~m}), 1516(\mathrm{w})$, 1500 (w), 1463 (s), 1444 (s), 1426 (s), 1417 (s), 1389 (s), 1366 $(\mathrm{m}), 1339(\mathrm{w}), 1293(\mathrm{~m}), 1272(\mathrm{~m}), 1233(\mathrm{w}), 1220(\mathrm{w}), 1198(\mathrm{~m})$, 1134 (s), 1113 (s), 1102 (s), $1080(\mathrm{~m}), 1030(\mathrm{w}), 999(\mathrm{w}), 978$ $(\mathrm{m}), 957(w), 920(w), 895(w), 882(w), 852(m), 826(m), 806$ (m), $794(\mathrm{~m}), 781(\mathrm{w}), 734(\mathrm{w}), 689(\mathrm{w}), 673(\mathrm{w}) \mathrm{cm}^{-1} ;{ }^{1} \mathrm{H}$ NMR $\left(500 \mathrm{MHz}, \mathrm{CDCl}_{3}\right): \delta_{\mathrm{H}}=10.05(\mathrm{~s}, 1 \mathrm{H}, \mathrm{CHO}), 9.39(\mathrm{dd}, 1 \mathrm{H}, \mathrm{J}=$ 11.0, $\left.3.5 \mathrm{~Hz}, \mathrm{H}_{8}\right), 9.33\left(\mathrm{~s}, 1 \mathrm{H}, \mathrm{H}_{4}\right), 7.56-7.54\left(\mathrm{~m}, 2 \mathrm{H}, \mathrm{H}_{6,7}\right), 6.91$ $(\mathrm{d}, 1 \mathrm{H}, J=13.1 \mathrm{~Hz}, \mathrm{CH}=\mathrm{CH}), 6.41(\mathrm{~d}, 1 \mathrm{H}, J=13.1 \mathrm{~Hz}, \mathrm{CH}=\mathrm{CH})$, 3.98 (s, $3 \mathrm{H}, \mathrm{CO}_{2} \mathrm{Me}$ ), 3.15 (sept, $1 \mathrm{H}, J=6.9 \mathrm{~Hz}, i-\mathrm{Pr}$ ), 3.05 (s, $\left.6 \mathrm{H}, \mathrm{NMe}_{2}\right), 1.38(\mathrm{~d}, 6 \mathrm{H}, J=6.9 \mathrm{~Hz}, i-\mathrm{Pr}) \mathrm{ppm} ;{ }^{13} \mathrm{C}$ NMR $(125$ $\left.\mathrm{MHz}, \mathrm{CDCl}_{3}\right): \delta_{\mathrm{C}}=187.44,167.02,158.41,153.90,152.42$, $146.55,145.40,136.05,134.23,132.91,132.30,119.24,112.12$, 92.52, 51.01, 40.97, 39.51, 24.55 ppm; HRMS (El-MS, positive): calcd for $\mathrm{C}_{20} \mathrm{H}_{23} \mathrm{NO}_{3}{ }^{+}[\mathrm{M}]^{+} 325.1673$; found: 325.1680 .

1,2,3-Triformylazulene (17): DMFDMA (1.07 g, $8.96 \mathrm{mmol})$ was added to a solution of $6(833 \mathrm{mg}, 4.20 \mathrm{mmol})$ in DMF $(6 \mathrm{~mL})$. The resulting mixture was refluxed for $4 \mathrm{~h}$. The reaction mixture 
was poured into water and extracted with $\mathrm{CH}_{2} \mathrm{Cl}_{2}$. The organic layer was washed with brine, dried with $\mathrm{Na}_{2} \mathrm{SO}_{4}$, and concentrated under reduced pressure to give crude enamine product as brown solid. To this crude enamine product $(1.06 \mathrm{~g})$ in a mixed solvent of THF $(12 \mathrm{~mL})$ and $\mathrm{H}_{2} \mathrm{O}(12 \mathrm{~mL})$ was added sodium periodate $(2.70 \mathrm{~g}, 12.6 \mathrm{mmol})$ and the mixture was stirred at room temperature for $3 \mathrm{~h}$. After the reaction mixture was filtered, the filtrate was extracted with $\mathrm{CH}_{2} \mathrm{Cl}_{2}$. The organic layer was dried over $\mathrm{Na}_{2} \mathrm{SO}_{4}$ and the solvent was removed under reduced pressure. The residue was purified by column chromatography on silica gel with $\mathrm{CH}_{2} \mathrm{Cl}_{2} / \mathrm{AcOEt}(50: 1)$ to give $17(712 \mathrm{mg}, 80 \%)$ as reddish purple solid. M.p. $242-243{ }^{\circ} \mathrm{C}$ (lit. 242-243 $\left.{ }^{\circ} \mathrm{C}\right) ;{ }^{6}{ }^{1} \mathrm{H}$ NMR $\left(500 \mathrm{MHz}, \mathrm{CDCl}_{3}\right): \delta_{\mathrm{H}}=11.22(\mathrm{~s}, 1 \mathrm{H}$, $\mathrm{CHO}$ ), 10.84 (s, 2H, CHO), 10.00 (d, 2H, J = 9.7 Hz, H4,8), 8.25 (t, $1 \mathrm{H}, J=9.7 \mathrm{~Hz}, \mathrm{H}_{6}$ ), 8.01 (t, $2 \mathrm{H}, J=9.9 \mathrm{~Hz}, \mathrm{H}_{5,7}$ ) ppm; Data are in agreement with those previously reported in reference 6.

\section{Methyl 3-fluoro-2-formylazulene-1-carboxylate}

(18):

DMFDMA (515 mg, $4.32 \mathrm{mmol}$ ) was added to a solution of 7 (471 $\mathrm{mg}, 2.16 \mathrm{mmol})$ in DMF ( $3 \mathrm{~mL})$. The resulting mixture was refluxed for $3 \mathrm{~h}$. The reaction mixture was poured into water and extracted with $\mathrm{CH}_{2} \mathrm{Cl}_{2}$. The organic layer was washed with brine, dried with $\mathrm{Na}_{2} \mathrm{SO}_{4}$, and concentrated under reduced pressure to give crude enamine product as brown solid. To this crude enamine product $(590 \mathrm{mg})$ in a mixed solvent of THF $(8 \mathrm{~mL})$ and $\mathrm{H}_{2} \mathrm{O}(8 \mathrm{~mL})$ was added sodium periodate $(1.39 \mathrm{~g}, 6.50 \mathrm{mmol})$ and the mixture was stirred at room temperature for $3 \mathrm{~h}$. After the reaction mixture was filtered, the filtrate was extracted with $\mathrm{CH}_{2} \mathrm{Cl}_{2}$. The organic layer was dried over $\mathrm{Na}_{2} \mathrm{SO}_{4}$ and the solvent was removed under reduced pressure. The residue was purified by column chromatography on silica gel with $\mathrm{CH}_{2} \mathrm{Cl}_{2}$ to give 18 (454 mg, 90\%) as green solid. M.p. $136-137^{\circ} \mathrm{C}$; IR (ATR): $v_{\max }=2965(w), 2892(w), 1682(s), 1577(w), 1513(w)$, $1472(w), 1438$ (s), $1421(\mathrm{~m}), 1409(w), 1400(\mathrm{~m}), 1381(\mathrm{w})$, $1315(w), 1298(w), 1236(w), 1202(s), 1181(m), 1138(s), 1044$ $(\mathrm{m}), 1017(\mathrm{w}), 1006(\mathrm{w}), 963(\mathrm{~m}), 899(\mathrm{~m}), 876(\mathrm{~m}), 800(\mathrm{w}), 777$ (s), $768(\mathrm{~m}), 740(\mathrm{~m}), 679(\mathrm{w}), 655(\mathrm{w}) \mathrm{cm}^{-1} ;{ }^{1} \mathrm{H}$ NMR $(500 \mathrm{MHz}$, $\left.\mathrm{CDCl}_{3}\right): \delta_{\mathrm{H}}=10.83(\mathrm{~s}, 1 \mathrm{H}, \mathrm{CHO}), 9.67(\mathrm{dd}, 1 \mathrm{H}, J=10.0,2.0 \mathrm{~Hz}$, $\left.\mathrm{H}_{4}\right), 8.60\left(\mathrm{~d}, 1 \mathrm{H}, J=10.0 \mathrm{~Hz}, \mathrm{H}_{8}\right), 7.90\left(\mathrm{t}, 1 \mathrm{H}, J=10.0 \mathrm{~Hz}, \mathrm{H}_{6}\right)$, $7.50\left(\mathrm{t}, 1 \mathrm{H}, J=10.0 \mathrm{~Hz}, \mathrm{H}_{5}\right), 7.42\left(\mathrm{t}, 1 \mathrm{H}, J=10.0 \mathrm{~Hz}, \mathrm{H}_{7}\right), 4.02$ (s, 3H, $\left.\mathrm{CO}_{2} \mathrm{Me}\right) \mathrm{ppm} ;{ }^{13} \mathrm{C}$ NMR $\left(125 \mathrm{MHz}, \mathrm{CDCl}_{3}\right): \delta_{\mathrm{C}}=190.3$, $165.0,150.6,148.4,144.0,143.3,138.0,134.0,128.4,127.3$, 127.2, 126.9, 110.0, 51.9 ppm; HRMS (MALDI-TOF): calcd for $\mathrm{C}_{13} \mathrm{H}_{9} \mathrm{FO}_{3}+\mathrm{Ag}^{+}[\mathrm{M}+\mathrm{Ag}]^{+}$338.9581; found: 338.9594 .

\section{Methyl 3-chloro-2-formylazulene-1-carboxylate}

(19): DMFDMA (413 mg, $3.46 \mathrm{mmol}$ ) was added to a solution of 8 $(412 \mathrm{mg}, 1.75 \mathrm{mmol})$ in DMF $(10 \mathrm{~mL})$. The resulting mixture was refluxed for $3 \mathrm{~h}$. The reaction mixture was poured into water and extracted with AcOEt. The organic layer was washed with brine, dried with $\mathrm{Na}_{2} \mathrm{SO}_{4}$, and concentrated under reduced pressure to give crude enamine product as brown oil. To this crude enamine product $(485 \mathrm{mg})$ in a mixed solvent of THF $(10 \mathrm{~mL})$ and $\mathrm{H}_{2} \mathrm{O}$ $(10 \mathrm{~mL})$ was added sodium periodate $(752 \mathrm{mg}, 3.51 \mathrm{mmol})$ and the mixture was stirred at room temperature for 1 day. After the reaction mixture was filtered, the filtrate was extracted with AcOEt. The organic layer was dried over $\mathrm{Na}_{2} \mathrm{SO}_{4}$ and the solvent was removed under reduced pressure. The residue was purified by column chromatography on silica gel with hexane/AcOEt $(4: 1)$ to give $19(270 \mathrm{mg}, 62 \%)$ as green solid. M.p. $156-158{ }^{\circ} \mathrm{C}$; IR (ATR): $v_{\max }=2958$ (w), 1691 (s), 1582 (w), $1541(w), 1500(w), 1460(m), 1433(s), 1411(m), 1393(m)$, $1365(\mathrm{~m}), 1297(\mathrm{w}), 1232(\mathrm{~m}), 1202(\mathrm{~s}), 1076(\mathrm{~s}), 1007(\mathrm{w}), 953$ $(w), 894(w), 834(w), 779(m), 739(m), 697(w), 686(w), 674$ (w), $656(\mathrm{w}) \mathrm{cm}^{-1} ;{ }^{1} \mathrm{H}$ NMR $\left(500 \mathrm{MHz}, \mathrm{CDCl}_{3}\right): \delta_{\mathrm{H}}=10.83(\mathrm{~s}, 1 \mathrm{H}$, $\mathrm{CHO}$ ), $9.64\left(\mathrm{~d}, 1 \mathrm{H}, J=10.0 \mathrm{~Hz}, \mathrm{H}_{8}\right), 8.74(\mathrm{~s}, 1 \mathrm{H}, J=10.0 \mathrm{~Hz}$, $\left.\mathrm{H}_{4}\right), 7.95\left(\mathrm{t}, 1 \mathrm{H}, J=10.0 \mathrm{~Hz}, \mathrm{H}_{6}\right), 7.61-7.55\left(\mathrm{~m}, 2 \mathrm{H}, \mathrm{H}_{5,7}\right), 4.01$ $\left(\mathrm{s}, 3 \mathrm{H}, \mathrm{CO}_{2} \mathrm{Me}\right) \mathrm{ppm} ;{ }^{13} \mathrm{C} \mathrm{NMR}\left(125 \mathrm{MHz}, \mathrm{CDCl}_{3}\right): \delta_{\mathrm{C}}=190.9$ 164.6, 143.4, 142.1, 140.0, 139.3, 139.2, 138.0, 129.2, 128.0, 117.3, 114.6, 52.0, ppm; HRMS (El-MS, positive): calcd for $\mathrm{C}_{13} \mathrm{H}_{9} \mathrm{ClO}_{3}{ }^{+}[\mathrm{M}]^{+}$248.0235; found: 248.0242 .

Methyl 3-bromo-2-formylazulene-1-carboxylate (20): DMFDMA (161 mg, $1.35 \mathrm{mmol}$ ) was added to a solution of 9 (188 $\mathrm{mg}, 0.673 \mathrm{mmol})$ in DMF $(5 \mathrm{~mL})$. The resulting mixture was refluxed for $3 \mathrm{~h}$. The reaction mixture was poured into water and extracted with AcOEt. The organic layer was washed with brine, dried with $\mathrm{Na}_{2} \mathrm{SO}_{4}$, and concentrated under reduced pressure to give crude enamine product as brown oil. To this crude enamine product $(153 \mathrm{mg})$ in a mixed solvent of THF $(5 \mathrm{~mL})$ and $\mathrm{H}_{2} \mathrm{O}(5$ $\mathrm{mL}$ ) was added sodium periodate $(287 \mathrm{mg}, 1.34 \mathrm{mmol})$ and the mixture was stirred at room temperature for 1 day. After the reaction mixture was filtered, the filtrate was extracted with AcOEt. The organic layer was dried over $\mathrm{Na}_{2} \mathrm{SO}_{4}$ and the solvent was removed under reduced pressure. The residue was purified by column chromatography on silica gel with hexane/AcOEt $(4: 1)$ to give $20(50 \mathrm{mg}, 25 \%)$ as green solid. M.p. $145-146^{\circ} \mathrm{C}$; IR (ATR): $v_{\max }=2954$ (w), 2886 (w), 1698 (s), $1684(\mathrm{~s}), 1578(\mathrm{w}), 1532(\mathrm{w}), 1455(\mathrm{~m}), 1429(\mathrm{~m}), 1414(\mathrm{~m})$, $1379(w), 1339(w), 1293(\mathrm{~m}), 1230(\mathrm{w}), 1193(\mathrm{~s}), 1070(\mathrm{~s}), 1050$ (s), $1002(w), 990(w), 965(w), 951(w), 894(w), 861(w), 823$ $(w), 796(w), 770(m), 736(m), 709(w) \mathrm{cm}^{-1} ;{ }^{1} \mathrm{H}$ NMR $(500 \mathrm{MHz}$ $\left.\mathrm{CDCl}_{3}\right): \delta_{\mathrm{H}}=10.76(\mathrm{~s}, 1 \mathrm{H}, \mathrm{CHO}), 9.60\left(\mathrm{~d}, 1 \mathrm{H}, J=10.0 \mathrm{~Hz}, \mathrm{H}_{8}\right)$, $8.72\left(\mathrm{~d}, 1 \mathrm{H}, J=10.0 \mathrm{~Hz}, \mathrm{H}_{8}\right), 7.94\left(\mathrm{t}, 1 \mathrm{H}, J=10.0 \mathrm{~Hz}, \mathrm{H}_{6}\right), 7.61$ (d, $1 \mathrm{H}, J=10.0 \mathrm{~Hz}, \mathrm{H}_{7}$ ), 7.59 (d, $1 \mathrm{H}, J=10.0 \mathrm{~Hz}, \mathrm{H}_{5}$ ), 4.00 (s, $\left.3 \mathrm{H}, \mathrm{CO}_{2} \mathrm{Me}\right) \mathrm{ppm} ;{ }^{13} \mathrm{C}$ NMR $\left(125 \mathrm{MHz}, \mathrm{CDCl}_{3}\right): \delta_{\mathrm{C}}=191.2$ 164.6, 143.1, 141.7, 141.5, 140.3, 139.7, 129.3, 128.3, 115.9, 104.9, 52.0, ppm; HRMS (EI-MS, positive): calcd for $\mathrm{C}_{13} \mathrm{H}_{9} \mathrm{BrO}_{3}{ }^{+}$ $[\mathrm{M}]^{+}$291.9730; found: 291.9729 .

trans-1-(2-Methyl-3-methoxycarbonyl-5-isopropylazulen-1yl)-2-(1-carboxy-3-formyl-7-isopropylazulen-2-yl)ethylene (23): To a solution of $5(811 \mathrm{mg}, 3.00 \mathrm{mmol})$ in $\mathrm{MeOH}(30 \mathrm{~mL})$ was added $\mathrm{Na}$ ( $367 \mathrm{mg}, 15.5 \mathrm{mmol})$. The resulting mixture was refluxed for $18 \mathrm{~h}$ under an $\mathrm{Ar}$ atmosphere. The reaction mixture was poured into water and neutralized with $\mathrm{HCl}$. The precipitate was collected by filtration to give $23(544 \mathrm{mg}, 70 \%)$ as brown crystals. M.p. $206-208{ }^{\circ} \mathrm{C}$; IR (ATR): $\mathrm{v}_{\max }=2956(\mathrm{w}), 2865(\mathrm{w})$, $1680(\mathrm{~m}), 1639$ (s), $1611(\mathrm{~m}), 1575$ (w), 1520 (w), 1437 (s), $1395(\mathrm{~m}), 1380(\mathrm{~m}), 1364(\mathrm{w}), 1303(\mathrm{w}), 1263(\mathrm{w}), 1238(\mathrm{~m})$, $1221(\mathrm{~s}), 1191(\mathrm{~m}), 1143(\mathrm{w}), 1105(\mathrm{~m}), 1069(\mathrm{w}), 995(\mathrm{w}), 977$ $(w), 966(w), 935(w), 880(w), 864(w), 846(w), 799(m), 782$ (m), $735(\mathrm{w}), 690(\mathrm{w}), 667(\mathrm{w}) \mathrm{cm}^{-1}$; UV/Vis $\left(\mathrm{CH}_{2} \mathrm{Cl}_{2}\right): \lambda_{\max }(\log \varepsilon)$ $=244$ (4.57), $295 \mathrm{sh}$ (4.67), 311 (4.73), 373 (4.43), $385 \mathrm{sh}$ (4.38), 476 (4.31) nm; ${ }^{1} \mathrm{H}$ NMR $\left(500 \mathrm{MHz}, \mathrm{CD}_{2} \mathrm{Cl}_{2}\right): \delta_{\mathrm{H}}=10.48(\mathrm{~s}, 1 \mathrm{H}$, $\mathrm{CHO}), 9.84\left(\mathrm{~m}, 2 \mathrm{H}, \mathrm{H}_{4^{\prime}, 8^{\prime}}\right), 9.51\left(\mathrm{~s}, 1 \mathrm{H}, \mathrm{H}_{4}\right), 8.76(\mathrm{~d}, 1 \mathrm{H}, J=9.7$ $\left.\mathrm{Hz}, \mathrm{H}_{8}\right), 8.01(\mathrm{~d}, 1 \mathrm{H}, J=16.6 \mathrm{~Hz}, \mathrm{CH}=\mathrm{CH}), 7.94(\mathrm{~d}, 1 \mathrm{H}, J=10.3$ $\left.\mathrm{Hz}, \mathrm{H}_{6^{\prime}}\right), 7.83\left(\mathrm{t}, 1 \mathrm{H}, J=10.2 \mathrm{~Hz}, \mathrm{H}_{5^{\prime}}\right), 7.55(\mathrm{~d}, 1 \mathrm{H}, J=10.0 \mathrm{~Hz}$, $\left.\mathrm{H}_{6}\right), 7.42\left(\mathrm{t}, 1 \mathrm{H}, J=9.9 \mathrm{~Hz}, \mathrm{H}_{7}\right), 7.35(\mathrm{~d}, 1 \mathrm{H}, J=16.6 \mathrm{~Hz}$, $\mathrm{CH}=\mathrm{CH}), 3.94\left(\mathrm{~s}, 3 \mathrm{H}, \mathrm{CO}_{2} \mathrm{Me}\right), 3.29$ (sept, $\left.1 \mathrm{H}, J=6.9 \mathrm{~Hz}, i-\mathrm{Pr}\right)$, 3.12 (sept, $1 \mathrm{H}, J=6.9 \mathrm{~Hz}, i-\mathrm{Pr}$ ), 2.94 (s, 3H, Me), 1.42 (d, $6 \mathrm{H}, J$ $=6.9 \mathrm{~Hz}, i-\operatorname{Pr}), 1.35(\mathrm{~d}, 6 \mathrm{H}, J=6.9 \mathrm{~Hz}, i-\operatorname{Pr}) \mathrm{ppm}$, proton signal 
of $\mathrm{CO}_{2} \mathrm{H}$ could not be observed due to the broadening of the signal; ${ }^{13} \mathrm{C}$ NMR $\left(125 \mathrm{MHz}, \mathrm{CD}_{2} \mathrm{Cl}_{2}\right): \delta_{\mathrm{C}}=188.3,169.8,166.5$, $158.2,154.9,152.4,149.9,145.6,144.1,142.4,140.1,140.0$, $138.5,137.5,136.9,136.2,134.5,133.4,133.1,127.8,125.2$, 124.7, 121.6, 115.4, 112.8, 50.9, 39.6, 39.2, 24.38, 24.36, 16.2 ppm; HRMS (FAB-MS, positive): calcd for $\mathrm{C}_{33} \mathrm{H}_{32} \mathrm{O}_{5}{ }^{+}[\mathrm{M}]^{+}$ 508.2245; found: 508.2249 .

1-Methyl-3-phenylazulene (24): To a solution of methyl 3phenylazulene-1-carboxylate $(1.95 \mathrm{~g}, 7.43 \mathrm{mmol})$ in $\mathrm{Et}_{2} \mathrm{O}(20$ $\mathrm{mL}$ ) was added $1 \mathrm{M}$ DIBAL $(45 \mathrm{~mL})$ at $-78{ }^{\circ} \mathrm{C}$ under an $\mathrm{Ar}$ atmosphere. The resulting mixture was stirred at room temperature for $14 \mathrm{~h}$. The reaction mixture was poured into water and extracted with hexane. The organic layer was washed with brine, dried with $\mathrm{Na}_{2} \mathrm{SO}_{4}$, and concentrated under reduced pressure. The residue was purified by silica gel column chromatography with hexane to give $24(1.48 \mathrm{~g}, 91 \%)$ as blue oil IR (ATR): $v_{\max }=3023(w), 2918(w), 1618(w), 1597(w), 1569$ $(m), 1533(w), 1496(m), 1433(m), 1410(w), 1364(m), 1311(w)$, $1205(\mathrm{w}), 1155(\mathrm{w}), 1069(\mathrm{~m}), 1026(\mathrm{~m}), 942(\mathrm{~m}), 912(\mathrm{~m}), 869$ (s), $835(\mathrm{~m}), 800(\mathrm{~m}), 765(\mathrm{~s}), 737$ (s), $700(\mathrm{~s}), 668(\mathrm{~s}) \mathrm{cm}^{-1} ;{ }^{1} \mathrm{H}$ NMR $\left(500 \mathrm{MHz}, \mathrm{CDCl}_{3}\right): \delta_{\mathrm{H}}=8.46\left(\mathrm{~d}, 1 \mathrm{H}, \mathrm{J}=9.7 \mathrm{~Hz}, \mathrm{H}_{4}\right), 8.25$ $\left(\mathrm{d}, 1 \mathrm{H}, J=9.7 \mathrm{~Hz}, \mathrm{H}_{8}\right), 7.88\left(\mathrm{~s}, 1 \mathrm{H}, \mathrm{H}_{2}\right), 7.62(\mathrm{~d}, 2 \mathrm{H}, J=7.7 \mathrm{~Hz}$, o-Ph), 7.55-7.49 (m, 3H, $\mathrm{H}_{6}$ and $\left.m-\mathrm{Ph}\right), 7.36(\mathrm{t}, 1 \mathrm{H}, \mathrm{J}=7.4 \mathrm{~Hz}$, p-Ph), 7.09-7.01 (m, 2H, $\left.\mathrm{H}_{5,7}\right), 2.73(\mathrm{~s}, 3 \mathrm{H}, \mathrm{Me}) \mathrm{ppm} ;{ }^{13} \mathrm{C}$ NMR $\left(125 \mathrm{MHz}, \mathrm{CDCl}_{3}\right): \delta_{\mathrm{C}}=138.2,138.1,137.9,137.5,135.4,135.2$ 134.2, 129.8, 129.7, 128.6, 126.2, 125.4, 122.5, 121.5, 12.7 ppm; HRMS (El-MS, positive): calcd for $\mathrm{C}_{17} \mathrm{H}_{14}{ }^{+}[\mathrm{M}]^{+}$218.1091; found: 218.1094.

6-Isopropyl-1-methyl-3-phenylazulene (25): To a solution of methyl 6-isopropyl-3-phenylazulene-1-carboxylate $(2.18 \mathrm{~g}, 7.18$ $\mathrm{mmol})$ in $\mathrm{Et}_{2} \mathrm{O}(20 \mathrm{~mL})$ was added $1.00 \mathrm{M}$ DIBAL $(45 \mathrm{~mL})$ at $-78{ }^{\circ} \mathrm{C}$ under an $\mathrm{Ar}$ atmosphere. The resulting mixture was stirred at room temperature for $12 \mathrm{~h}$. The reaction mixture was poured into water and extracted with hexane. The organic layer was washed with brine, dried with $\mathrm{Na}_{2} \mathrm{SO}_{4}$, and concentrated under reduced pressure. The residue was purified by silica gel column chromatography with hexane to give $25(1.74 \mathrm{~g}, 93 \%)$ as blue oil. IR (ATR): $v_{\max }=2960(w), 2926(w), 2870(w), 1597(w)$, 1577 (s), 1496 (w), $1462(w), 1437(w), 1379(w), 1363(w)$, $1325(w), 1239(w), 1206(w), 1156(w), 1071(w), 1040(m), 957$ $(\mathrm{w}), 913(\mathrm{w}), 865(\mathrm{~m}), 830(\mathrm{~s}), 764(\mathrm{~s}), 699(\mathrm{~s}), 676(\mathrm{~m}), 665(\mathrm{w})$, $656(\mathrm{w}) \mathrm{cm}^{-1} ;{ }^{1} \mathrm{H}$ NMR $\left(500 \mathrm{MHz}, \mathrm{CDCl}_{3}\right): \delta_{\mathrm{H}}=8.48(\mathrm{~d}, 1 \mathrm{H}, \mathrm{J}=$ $\left.10.0 \mathrm{~Hz}, \mathrm{H}_{4}\right), 8.24$ (d, $\left.1 \mathrm{H}, \mathrm{J}=10.0 \mathrm{~Hz}, \mathrm{H}_{8}\right), 7.85\left(\mathrm{~s}, 1 \mathrm{H}, \mathrm{H}_{2}\right), 7.69$ (d, $2 \mathrm{H}, J=7.4 \mathrm{~Hz}, o-\mathrm{Ph}), 7.55$ (t, $2 \mathrm{H}, J=7.4 \mathrm{~Hz}, m-\mathrm{Ph}), 7.40$ (t, $1 \mathrm{H}, J=7.4 \mathrm{~Hz}, p-\mathrm{Ph}), 7.05\left(\mathrm{~m}, 2 \mathrm{H}, \mathrm{H}_{5,7}\right), 3.07$ (sept, $1 \mathrm{H}, J=6.9$ $\mathrm{Hz}, i-\mathrm{Pr}$ ), 2.76 (s, 3H, Me), 1.41 (d, $6 \mathrm{H}, \mathrm{J}=6.9 \mathrm{~Hz}, i-\mathrm{Pr}$ ) ppm; ${ }^{13} \mathrm{C}$ NMR $\left(125 \mathrm{MHz}, \mathrm{CDCl}_{3}\right): \delta_{\mathrm{C}}=160.1,137.7,137.0,136.7,134.9$, $133.9,129.7,129.5,128.6,126.0,125.3,121.7,120.6,39.7$, 24.3, 12.6 ppm; HRMS (EI-MS, positive): calcd for $\mathrm{C}_{20} \mathrm{H}_{20}{ }^{+}[\mathrm{M}]^{+}$ 260.1560; found: 260.1568 .

2-Formyl-1-methyl-3-phenylazulene (26): $\mathrm{POCl}_{3}(920 \mathrm{mg}, 6.00$ $\mathrm{mmol}$ ) was added at $0{ }^{\circ} \mathrm{C}$ to a solution of $24(437 \mathrm{mg}, 2.00$ $\mathrm{mmol})$ in DMF $(10 \mathrm{~mL})$. The resulting mixture was stirred at room temperature for $12 \mathrm{~h}$. The reaction mixture was poured into $\mathrm{K}_{2} \mathrm{CO}_{3}$ aq. and extracted with hexane/AcOEt. The organic layer was washed with brine, dried with $\mathrm{Na}_{2} \mathrm{SO}_{4}$, and concentrated under reduced pressure. The residue was purified by column chromatography on silica gel with hexane/AcOEt $(4: 1)$ to give
26 (133 mg, 27\%) as green solid. M.p. $131-132{ }^{\circ} \mathrm{C}$; IR (ATR): $\mathrm{V}_{\max }=2833(\mathrm{w}), 2736(\mathrm{w}), 1666(\mathrm{~s}), 1599(\mathrm{w}), 1569(\mathrm{~m}), 1479$ $(w), 1450(m), 1429(m), 1378(m), 1293(w), 1229(w), 1179(w)$, $1147(\mathrm{~m}), 1101(\mathrm{~m}), 1075(\mathrm{w}), 1041(\mathrm{w}), 1001(\mathrm{~m}), 950(\mathrm{w}), 920$ $(\mathrm{w}), 890(\mathrm{~m}), 854(\mathrm{w}), 826(\mathrm{~m}), 789(\mathrm{~m}), 747(\mathrm{~s}), 733(\mathrm{~s}), 718(\mathrm{~s})$, $701(\mathrm{~s}), 669(\mathrm{~m}), 653(\mathrm{~m}) \mathrm{cm}^{-1} ;{ }^{1} \mathrm{H} \mathrm{NMR}\left(500 \mathrm{MHz}, \mathrm{CDCl}_{3}\right): \delta_{\mathrm{H}}=$ $10.41(\mathrm{~s}, 1 \mathrm{H}, \mathrm{CHO}), 8.43\left(\mathrm{~d}, 1 \mathrm{H}, J=10.0 \mathrm{~Hz}, \mathrm{H}_{4}\right), 8.26(\mathrm{~d}, 1 \mathrm{H}, J$ $\left.=9.5 \mathrm{~Hz}, \mathrm{H}_{8}\right), 7.57\left(\mathrm{t}, 1 \mathrm{H}, J=9.7 \mathrm{~Hz}, \mathrm{H}_{6}\right), 7.51(\mathrm{t}, 2 \mathrm{H}, J=7.4 \mathrm{~Hz}$, o-Ph), 7.43-7.46 (m, 3H, m,p-Ph), 7.06 (t, $1 \mathrm{H}, J=9.7 \mathrm{~Hz}, \mathrm{H}_{7}$ ), $6.98\left(\mathrm{t}, 1 \mathrm{H}, \mathrm{J}=9.7 \mathrm{~Hz}, \mathrm{H}_{5}\right), 2.90(\mathrm{~s}, 3 \mathrm{H}, \mathrm{Me}) \mathrm{ppm} ;{ }^{13} \mathrm{C} \mathrm{NMR}(125$ $\left.\mathrm{MHz}, \mathrm{CDCl}_{3}\right): \delta_{\mathrm{C}}=193.0,142.0,140.3,139.4,137.9,137.6$, $136.9,134.5,134.2,132.0,128.4,127.4,126.5,123.6,122.7$, $11.6 \mathrm{ppm}$; HRMS (MALDI-TOF): calcd for $\mathrm{C}_{18} \mathrm{H}_{14} \mathrm{O}^{+}[\mathrm{M}]^{+}$ 246.1039; found: 246.1045; HRMS (MALDI-TOF): calcd for $\mathrm{C}_{18} \mathrm{H}_{14} \mathrm{O}+\mathrm{Ag}^{+}\left[\mathrm{M}+\mathrm{Ag}^{+}\right.$353.0090; found: 353.0115. Structure of 26 was also determined by single crystal X-ray analysis (Figure 6).

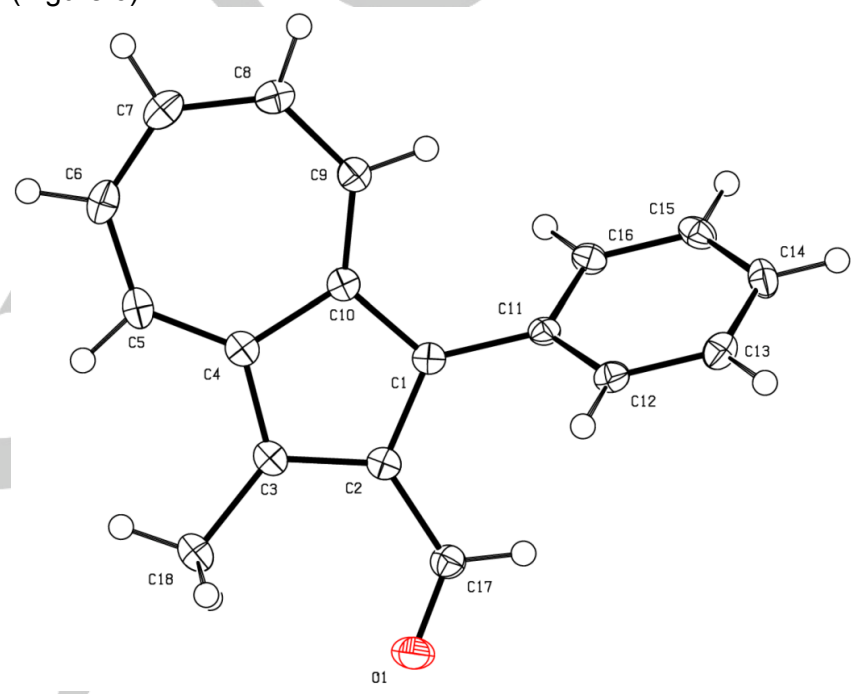

Figure 6. ORTEP Drawing of 26; Ellipsoids are drawn at 50\% probability. ${ }^{[14]}$

2-Formyl-6-isopropyl-1-methyl-3-phenylazulene (27): $\mathrm{POCl}_{3}$ $(1.03 \mathrm{~g}, 6.72 \mathrm{mmol})$ was added at $0{ }^{\circ} \mathrm{C}$ to a solution of 25 (583 $\mathrm{mg}, 2.24 \mathrm{mmol})$ in DMF $(15 \mathrm{~mL})$. The resulting mixture was stirred at room temperature for $12 \mathrm{~h}$. The reaction mixture was poured into $\mathrm{K}_{2} \mathrm{CO}_{3}$ aq. and extracted with hexane/AcOEt. The organic layer was washed with brine, dried with $\mathrm{Na}_{2} \mathrm{SO}_{4}$, and concentrated under reduced pressure. The residue was purified by column chromatography on silica gel with hexane/AcOEt (4 : 1) to give 27 (335 mg, 52\%) as green solid. M.p. $84-86{ }^{\circ} \mathrm{C}$; IR (ATR): $v_{\max }=2967(w), 2926(w), 2737(w), 1670(s), 1577(s)$, $1482(\mathrm{~m}), 1446(\mathrm{~m}), 1429(\mathrm{~m}), 1389(\mathrm{w}), 1378(\mathrm{w}), 1329(\mathrm{w})$, $1246(m), 1179(w), 1131(w), 1110(w), 1074(w), 1040(w)$, $1029(w), 923(w), 885(w), 862(w), 837(s), 793(w), 751(m)$, $723(\mathrm{~m}), 703(\mathrm{~m}), 686(\mathrm{w}), 670(\mathrm{w}), 656(\mathrm{w}) \mathrm{cm}^{-1} ;{ }^{1} \mathrm{H}$ NMR $(500$ $\left.\mathrm{MHz}, \mathrm{CDCl}_{3}\right): \delta_{\mathrm{H}}=10.38(\mathrm{~s}, 1 \mathrm{H}, \mathrm{CHO}), 8.37(\mathrm{~d}, 1 \mathrm{H}, J=10.3 \mathrm{~Hz}$, $\left.\mathrm{H}_{4}\right), 8.21\left(\mathrm{~d}, 1 \mathrm{H}, J=10.3 \mathrm{~Hz}, \mathrm{H}_{8}\right), 7.49-7.52(\mathrm{t}, 2 \mathrm{H}, J=7.4 \mathrm{~Hz}$, o-Ph), 7.45-7.41 (m, 3H, m,p-Ph), 7.02 (d, $1 \mathrm{H}, J=10.3 \mathrm{~Hz}, \mathrm{H}_{5}$ ), $6.93\left(\mathrm{~d}, 1 \mathrm{H}, J=10.0 \mathrm{~Hz}, \mathrm{H}_{7}\right.$ ), 3.00 (sept, $1 \mathrm{H}, J=6.9 \mathrm{~Hz}, i-\mathrm{Pr}$ ), $2.88\left(\mathrm{~s}, 3 \mathrm{H}, \mathrm{Me}\right.$ ), $1.33(\mathrm{~d}, 6 \mathrm{H}, J=6.9 \mathrm{~Hz}, i-\mathrm{Pr}) \mathrm{ppm} ;{ }^{13} \mathrm{C}$ NMR $\left(125 \mathrm{MHz}, \mathrm{CDCl}_{3}\right): \delta_{\mathrm{C}}=192.9,165.1,140.0,139.1,137.0,136.2$, $135.6,134.5,134.4,132.0,128.3,127.3,126.5,122.7,122.2$, 40.0, 24.0, 11.6 ppm; HRMS (MALDI-TOF): calcd for $\mathrm{C}_{21} \mathrm{H}_{20} \mathrm{O}^{+}$ 
[M] 288.1509; found: 288.1516; HRMS (MALDI-TOF): calcd for $\mathrm{C}_{21} \mathrm{H}_{20} \mathrm{O}+\mathrm{Ag}^{+}[\mathrm{M}+\mathrm{Ag}]^{+}$395.0560; found: 395.0538 .

Methyl 2-formyl-3-iodoazulene-1-carboxylate (21): To a solution of 13 (100 mg, $0.467 \mathrm{mmol})$ in $\mathrm{CH}_{2} \mathrm{Cl}_{2}(5 \mathrm{~mL})$ was added $\mathrm{N}$-iodosuccinimide (316 $\mathrm{mg}, 1.41 \mathrm{mmol}$ ) at room temperature. The resulting mixture was stirred at room temperature for $18 \mathrm{~h}$ under an $\mathrm{Ar}$ atmosphere. After the solvent was removed under reduced pressure, the crude product was purified by silica gel column chromatography with $\mathrm{CH}_{2} \mathrm{Cl}_{2}$ to give 21 (156 mg, 98\%) as green solid. M.p. $145-146{ }^{\circ} \mathrm{C}$; IR (ATR): $\mathrm{v}_{\max }=2947(\mathrm{w}), 2885(\mathrm{w}), 1686(\mathrm{~s}), 1577(\mathrm{w}), 1533(\mathrm{w}), 1455$ $(\mathrm{m}), 1438(\mathrm{~m}), 1409(\mathrm{~m}), 1379(\mathrm{w}), 1328(\mathrm{~m}), 1298(\mathrm{w}), 1289(\mathrm{w})$ $1230(\mathrm{~m}), 1200(\mathrm{~s}), 1154(\mathrm{w}), 1064(\mathrm{~m}), 1046(\mathrm{~m}), 1003(\mathrm{w}), 982$ $(w), 951(w), 893(m), 862(w), 816(w), 794(w), 769(m), 735$ $(\mathrm{m}), 712(\mathrm{w}), 695(\mathrm{w}), 678(\mathrm{w}) \mathrm{cm}^{-1} ;{ }^{1} \mathrm{H}$ NMR (500 MHz, $\left.\mathrm{CDCl}_{3}\right)$ : $\delta_{\mathrm{H}}=10.74(\mathrm{~s}, 1 \mathrm{H}, \mathrm{CHO}), 9.62\left(\mathrm{~d}, 1 \mathrm{H}, J=10.0 \mathrm{~Hz}, \mathrm{H}_{8}\right), 8.73(\mathrm{~d}$, $\left.1 \mathrm{H}, J=10.0 \mathrm{~Hz}, \mathrm{H}_{4}\right), 7.96\left(\mathrm{t}, 1 \mathrm{H}, J=10.0 \mathrm{~Hz}, \mathrm{H}_{6}\right), 7.65(\mathrm{t}, 2 \mathrm{H}, J$ $\left.=10.0 \mathrm{~Hz}, \mathrm{H}_{5,7}\right), 4.02\left(\mathrm{~s}, 3 \mathrm{H}, \mathrm{CO}_{2} \mathrm{Me}\right) \mathrm{ppm} ;{ }^{13} \mathrm{C} \mathrm{NMR}(125 \mathrm{MHz}$, $\left.\mathrm{CDCl}_{3}\right): \delta_{\mathrm{C}}=192.0,164.6,145.1,144.8,143.2,142.7,142.0$, $141.2,129.5,128.6,118.2,76.5,52.0$ ppm; HRMS (EI-MS, positive): calcd for $\mathrm{C}_{13} \mathrm{H}_{9} \mathrm{IO}_{3}{ }^{+}[\mathrm{M}]^{+} 339.9591$; found: 339.9606 .

Methyl 2-formyl-3-iodo-7-isopropylazulene-1-carboxylate (28): To a solution of 12 (256 mg, $1.00 \mathrm{mmol})$ in $\mathrm{CH}_{2} \mathrm{Cl}_{2}(7 \mathrm{~mL})$ was added $\mathrm{N}$-iodosuccinimide (451 $\mathrm{mg}, 2.00 \mathrm{mmol}$ ) at room temperature. The resulting mixture was stirred at room temperature for $2 \mathrm{~h}$ under an $\mathrm{Ar}$ atmosphere. After the solvent was removed under reduced pressure, the crude product was purified by silica gel column chromatography with toluene/AcOEt (50: 1) to give 28 (342 mg, 90\%) as green solid. M.p. 133-135 ${ }^{\circ} \mathrm{C}$; IR (ATR): $v_{\max }=2948(w), 2889(w), 1686(s), 1672$ $(\mathrm{s}), 1577(w), 1520(w), 1446(\mathrm{~m}), 1414(\mathrm{~m}), 1397(\mathrm{w}), 1376(\mathrm{w})$, $1335(w), 1303(w), 1279(w), 1222(s), 1198(m), 1171(w)$, $1125(w), 1069(m), 1015(m), 975(m), 930(w), 890(w), 824$ $(\mathrm{m}), 806(\mathrm{~m}), 772(\mathrm{~m}), 745(\mathrm{w}), 685(\mathrm{w}), 675(\mathrm{w}), 667(\mathrm{w}), 657$ (w) $\mathrm{cm}^{-1} ;{ }^{1} \mathrm{H}$ NMR $\left(500 \mathrm{MHz}, \mathrm{CDCl}_{3}\right): \delta_{\mathrm{H}}=10.73(\mathrm{~s}, 1 \mathrm{H}, \mathrm{CHO})$, $9.74\left(\mathrm{~s}, 1 \mathrm{H}, \mathrm{H}_{8}\right), 8.62\left(\mathrm{~d}, 1 \mathrm{H}, \mathrm{J}=10.0 \mathrm{~Hz}, \mathrm{H}_{4}\right), 7.92(\mathrm{~d}, 1 \mathrm{H}, \mathrm{J}=$ $\left.10.0 \mathrm{~Hz}, \mathrm{H}_{6}\right), 7.62\left(\mathrm{t}, 1 \mathrm{H}, \mathrm{J}=10.0 \mathrm{~Hz}, \mathrm{H}_{5}\right), 4.01\left(\mathrm{~s}, 3 \mathrm{H}, \mathrm{CO}_{2} \mathrm{Me}\right)$, 3.24 (sept, $1 \mathrm{H}, J=6.9 \mathrm{~Hz}, i-\mathrm{Pr}), 1.43(\mathrm{~d}, 6 \mathrm{H}, J=6.9 \mathrm{~Hz}, i-\mathrm{Pr})$ ppm; ${ }^{13} \mathrm{C}$ NMR $\left(125 \mathrm{MHz}, \mathrm{CDCl}_{3}\right): \delta_{\mathrm{C}}=192.3,164.7,151.1$, 145.0, 143.3, 143.2, 142.13, 142.05, 140.8, 128.4, 116.8, 74.8, 51.9, 39.3, 24.6 ppm; HRMS (MALDI-TOF): calcd for $\mathrm{C}_{16} \mathrm{H}_{15} \mathrm{IO}$ $+\mathrm{Ag}^{+}[\mathrm{M}+\mathrm{Ag}]^{+}$488.9111; found: 488.9118 .

Methyl 2-formyl-7-isopropyl-3-phenylethynylazulene-1carboxylate (29): To a degassed solution of 21 (336 mg, 0.880 $\mathrm{mmol})$, ethynylbenzene (182 $\mathrm{mg}, 1.78 \mathrm{mmol})$, and Cul $(20 \mathrm{mg}$, $0.11 \mathrm{mmol})$ in THF $(5 \mathrm{~mL})$ and triethylamine $(5 \mathrm{~mL})$ was added tetrakis(triphenylphosphine)palladium(0) $(36 \mathrm{mg}, 0.031 \mathrm{mmol}$ ). The resulting mixture was stirred at $50{ }^{\circ} \mathrm{C}$ for $2 \mathrm{~h}$ under an $\mathrm{Ar}$ atmosphere. The reaction mixture was poured into a $10 \% \mathrm{NH}_{4} \mathrm{Cl}$ solution and extracted with AcOEt. The organic layer was washed with brine, dried over $\mathrm{Na}_{2} \mathrm{SO}_{4}$, and concentrated under reduced pressure. The residue was purified by column chromatography on silica gel with toluene/AcOEt $(50: 1)$ to give 29 (288 mg, 92\%) as green solid. M.p. $133-133.5^{\circ} \mathrm{C}$; IR (ATR): $\mathrm{V}_{\max }=2954(w), 2897(w), 2197(w), 1683(s), 1597(w), 1578$ $(w), 1481(m), 1446(m), 1401(w), 1377(w), 1362(w), 1337(w)$, $1306(\mathrm{w}), 1272(\mathrm{w}), 1241(\mathrm{~m}), 1216(\mathrm{~s}), 1195(\mathrm{~m}), 1108(\mathrm{~m})$, $1048(m), 1027(w), 1003(w), 962(w), 933(w), 873(w), 833(w)$, $804(\mathrm{~m}), 762(\mathrm{~m}), 695(\mathrm{~m}), 668(\mathrm{w}), 656(\mathrm{w}) \mathrm{cm}^{-1} ;{ }^{1} \mathrm{H}$ NMR (500 $\left.\mathrm{MHz}, \mathrm{CDCl}_{3}\right): \delta_{\mathrm{H}}=10.92(\mathrm{~s}, 1 \mathrm{H}, \mathrm{CHO}), 9.76\left(\mathrm{~s}, 1 \mathrm{H}, \mathrm{H}_{4}\right), 8.84(\mathrm{~d}$, $\left.1 \mathrm{H}, J=10.0 \mathrm{~Hz}, \mathrm{H}_{8}\right), 7.90\left(\mathrm{~d}, 1 \mathrm{H}, J=10.0 \mathrm{~Hz}, \mathrm{H}_{6}\right), 7.67(\mathrm{~d}, 2 \mathrm{H}, J$ $=7.2 \mathrm{~Hz}, o-\mathrm{Ph}), 7.56\left(\mathrm{t}, 1 \mathrm{H}, J=10.0 \mathrm{~Hz}, \mathrm{H}_{7}\right), 7.36(\mathrm{~m}, 3 \mathrm{H}, m, p-$ $\mathrm{Ph}$ ), 4.03 (s, 3H, $\mathrm{CO}_{2} \mathrm{Me}$ ), 3.23 (sept, $\left.1 \mathrm{H}, J=6.9 \mathrm{~Hz}, i-\mathrm{Pr}\right), 1.43$ $(\mathrm{d}, 6 \mathrm{H}, J=6.9 \mathrm{~Hz}, i-\mathrm{Pr}) \mathrm{ppm} ;{ }^{13} \mathrm{C}$ NMR $\left(125 \mathrm{MHz}, \mathrm{CDCl}_{3}\right): \delta_{\mathrm{C}}=$ $191.3,165.2,151.5,144.8,143.9,142.6,141.7,141.3,140.2$, $131.8,128.4,128.3,123.7,114.7,110.1,96.6,83.7,51.8,39.4$, $24.6 \mathrm{ppm}$, one signal is overlapped with the other; HRMS (MALDI-TOF): calcd for $\mathrm{C}_{24} \mathrm{H}_{20} \mathrm{O}_{3}+\mathrm{Ag}^{+}[\mathrm{M}+\mathrm{Ag}]^{+} 463.0458$; found: 463.0469 .

Methyl 2-formyl-7-isopropyl-3-phenylazulene-1-carboxylate (30): To a solution of 21 (192 $\mathrm{mg}, 0.502 \mathrm{mmol})$, phenylboronic acid (122 mg, $1.00 \mathrm{mmol})$, and $\mathrm{K}_{2} \mathrm{CO}_{3}(211 \mathrm{mg}, 1.53 \mathrm{mmol})$ in 1,4-dioxane $(5 \mathrm{~mL})$ and $\mathrm{H}_{2} \mathrm{O}(0.5 \mathrm{~mL})$ was added tetrakis(triphenylphosphine)palladium(0) $(32 \mathrm{mg}, 0.0277 \mathrm{mmol})$. The resulting mixture was refluxed for $19 \mathrm{~h}$ under an $\mathrm{Ar}$ atmosphere. The reaction mixture was poured into water and extracted with AcOEt. The organic layer was washed with brine, dried with $\mathrm{Na}_{2} \mathrm{SO}_{4}$, and concentrated under reduced pressure. The residue was purified by recrystallization from $\mathrm{CH}_{2} \mathrm{Cl}_{2} / \mathrm{MeOH}$ to give 30 (159 mg, 95\%) as green needles. M.p. 107-108 ${ }^{\circ} \mathrm{C}$; IR (ATR): $v_{\max }=2962(w), 2947(w), 2871(w), 1684(s), 1598$ $(w), 1577(w), 1507(w), 1442(s), 1401(w), 1378(w), 1362(w)$, $1309(w), 1282(w), 1227(m), 1188(m), 1171(s), 1131(w)$, $1119(w), 1073(m), 1056(m), 1036(w), 1024(w), 1001(w), 989$ $(\mathrm{m}), 963(\mathrm{w}), 947(\mathrm{w}), 883(\mathrm{w}), 847(\mathrm{w}), 810(\mathrm{~m}), 776(\mathrm{~m}), 755$ $(\mathrm{m}), 744(\mathrm{~m}), 700(\mathrm{~s}), 679(\mathrm{w}), 663(\mathrm{w}) \mathrm{cm}^{-1}$; ${ }^{1} \mathrm{H}$ NMR $(500 \mathrm{MHz}$, $\left.\mathrm{CDCl}_{3}\right): \delta_{\mathrm{H}}=10.78(\mathrm{~s}, 1 \mathrm{H}, \mathrm{CHO}), 9.76\left(\mathrm{~d}, 1 \mathrm{H}, J=1.4 \mathrm{~Hz}, \mathrm{H}_{8}\right)$, $8.33\left(\mathrm{~d}, 1 \mathrm{H}, J=10.0 \mathrm{~Hz}, \mathrm{H}_{4}\right), 7.83\left(\mathrm{~d}, 1 \mathrm{H}, J=10.0 \mathrm{~Hz}, \mathrm{H}_{6}\right), 7.48$ (t, $2 \mathrm{H}, J=7.3 \mathrm{~Hz}, o-\mathrm{Ph}), 7.36-7.43\left(\mathrm{~m}, 4 \mathrm{H}, \mathrm{H}_{5}\right.$ and $\left.m, p-\mathrm{Ph}\right)$, 4.03 (s, 3H, $\mathrm{CO}_{2} \mathrm{Me}$ ), 3.24 (sept, $1 \mathrm{H}, J=6.9 \mathrm{~Hz}, i-\mathrm{Pr}$ ), 1.44 (d, $6 \mathrm{H}, \mathrm{J}=6.9 \mathrm{~Hz}, i-\mathrm{Pr}) \mathrm{ppm} ;{ }^{13} \mathrm{C} \mathrm{NMR}\left(125 \mathrm{MHz}, \mathrm{CDCl}_{3}\right): \delta_{\mathrm{C}}=$ 193.0, 165.8, 149.8, 143.1, 141.5, 141.3, 140.7, 140.6, 139.7, $134.3,131.4,131.0,128.2,127.52,127.50,113.8,51.8,39.2$, 24.7 ppm; HRMS (MALDI-TOF): calcd for $\mathrm{C}_{22} \mathrm{H}_{20} \mathrm{O}_{3}+\mathrm{Ag}^{+}[\mathrm{M}+$ $\mathrm{Ag}^{+}$439.0458; found: 439.0452. Structure of 30 was also determined by single crystal X-ray analysis (Figure 7).

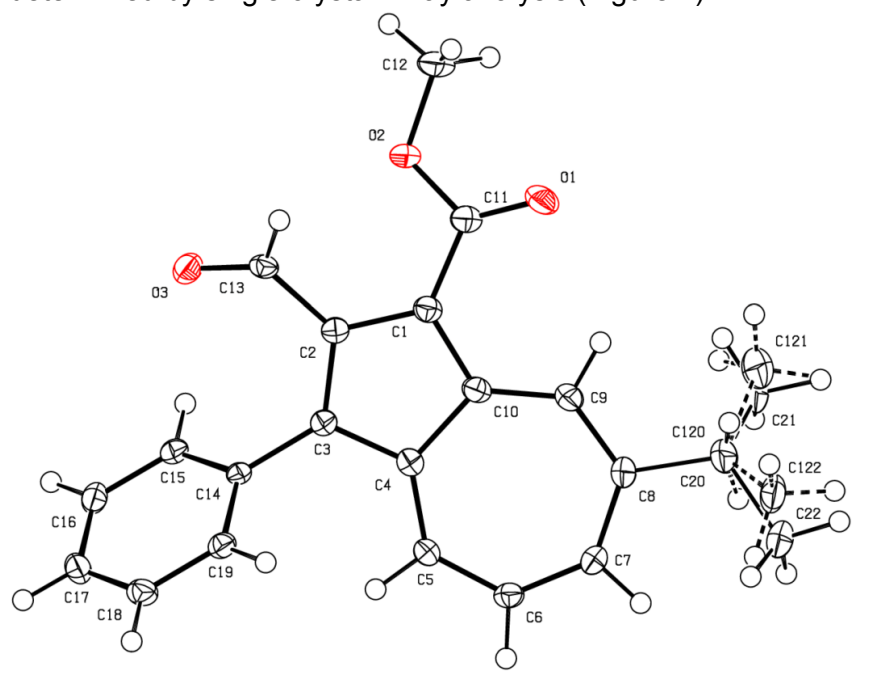

Figure 7. ORTEP Drawing of 30; Ellipsoids are drawn at 50\% probability. ${ }^{[14]}$ 
Methyl 2-ethynyl-7-isopropylazulene-1-carboxylate (32): To a solution of $12(128 \mathrm{mg}, 0.500 \mathrm{mmol})$ and $\mathrm{K}_{2} \mathrm{CO}_{3}(217 \mathrm{mg}, 1.57$ $\mathrm{mmol})$ in $\mathrm{MeOH}(5 \mathrm{~mL})$ was added $31(165 \mathrm{mg}, 0.650 \mathrm{mmol})$. The resulting mixture was stirred at room temperature for $1.5 \mathrm{~h}$ under an Ar atmosphere. The reaction mixture was poured into water and extracted with AcOEt. The organic layer was washed with brine, dried with $\mathrm{Na}_{2} \mathrm{SO}_{4}$, and concentrated under reduced pressure. The residue was purified by silica gel column chromatography with toluene to give 32 (109 $\mathrm{mg}, 85 \%)$ as purple oil. IR (ATR): $v_{\max }=2960(w), 2100(w), 1683(\mathrm{~s}), 1577$ (w), $1523(\mathrm{w}), 1466(\mathrm{~m}), 1446(\mathrm{~s}), 1418(\mathrm{~s}), 1380(\mathrm{~m}), 1364(\mathrm{w})$, $1341(\mathrm{~m}), 1303(\mathrm{w}), 1222(\mathrm{~s}), 1199(\mathrm{~m}), 1181(\mathrm{~m}), 1129(\mathrm{w})$, $1062(\mathrm{~s}), 1030(\mathrm{~m}), 1010(\mathrm{w}), 957(\mathrm{w}), 936(\mathrm{w}), 881(\mathrm{w}), 821(\mathrm{~m})$, $777(\mathrm{~m}), 696(\mathrm{w}), 668(\mathrm{~m}) \mathrm{cm}^{-1} ;{ }^{1} \mathrm{H}$ NMR $\left(500 \mathrm{MHz}, \mathrm{CDCl}_{3}\right): \delta_{\mathrm{H}}=$ $9.68\left(\mathrm{~s}, 1 \mathrm{H}, \mathrm{H}_{8}\right), 8.25\left(\mathrm{~d}, 1 \mathrm{H}, J=9.7 \mathrm{~Hz}, \mathrm{H}_{4}\right), 7.72(\mathrm{~d}, 1 \mathrm{H}, J=$ $\left.10.0 \mathrm{~Hz}, \mathrm{H}_{6}\right), 7.42-7.37\left(\mathrm{~m}, 2 \mathrm{H}, \mathrm{H}_{3,5}\right), 4.00$ (s, 3H, $\left.\mathrm{CO}_{2} \mathrm{Me}\right), 3.72$ (s, $1 \mathrm{H}, \mathrm{C} \equiv \mathrm{CH}$ ), 3.21 (sept, $1 \mathrm{H}, J=6.9 \mathrm{~Hz}, i-\mathrm{Pr}), 1.41(\mathrm{~d}, 6 \mathrm{H}, J=$ $6.9 \mathrm{~Hz}, i-\mathrm{Pr}) \mathrm{ppm} ;{ }^{13} \mathrm{C}$ NMR $\left(125 \mathrm{MHz}, \mathrm{CDCl}_{3}\right): \delta_{\mathrm{C}}=165.5,149.8$ $142.8,141.1,138.9,138.4,136.7,131.4,127.4,122.6,116.3$, 86.5, 81.5, 51.1, 39.4, 24.7 ppm; HRMS (MALDI-TOF): calcd for $\mathrm{C}_{17} \mathrm{H}_{16} \mathrm{O}_{2}+\mathrm{H}^{+}[\mathrm{M}+\mathrm{H}]^{+}$253.1223; found: 253.1225 .

Methyl 2-ethynylazulene-1-carboxylate (33): To a solution of $13(100 \mathrm{mg}, 0.467 \mathrm{mmol})$ and $\mathrm{K}_{2} \mathrm{CO}_{3}(211 \mathrm{mg}, 1.53 \mathrm{mmol})$ in $\mathrm{MeOH}(5 \mathrm{~mL})$ was added $31(156 \mathrm{mg}, 0.614 \mathrm{mmol})$. The resulting mixture was stirred at room temperature for $4 \mathrm{~h}$ under an $\mathrm{Ar}$ atmosphere. The reaction mixture was poured into water and extracted with AcOEt. The organic layer was washed with brine, dried with $\mathrm{Na}_{2} \mathrm{SO}_{4}$, and concentrated under reduced pressure. The residue was purified by silica gel column chromatography with toluene to give $\mathbf{3 3}(57 \mathrm{mg}, 58 \%)$ as purple solid. M.p. $99-99.5{ }^{\circ} \mathrm{C}$ (lit. 98.5-99.0 $\left.{ }^{\circ} \mathrm{C}\right) ;{ }^{4 \mathrm{~d}}{ }^{1} \mathrm{H}$ NMR $(500 \mathrm{MHz}$, $\left.\mathrm{CDCl}_{3}\right): \delta_{\mathrm{H}}=9.56\left(\mathrm{~d}, 1 \mathrm{H}, J=10.0 \mathrm{~Hz}, \mathrm{H}_{8}\right), 8.36(\mathrm{~d}, 1 \mathrm{H}, J=10.0$ $\left.\mathrm{Hz}, \mathrm{H}_{4}\right), 7.77\left(\mathrm{t}, 1 \mathrm{H}, J=10.0 \mathrm{~Hz}, \mathrm{H}_{6}\right), 7.56(\mathrm{t}, 1 \mathrm{H}, J=10.0 \mathrm{~Hz}$, $\left.\mathrm{H}_{7}\right), 7.45\left(\mathrm{~m}, 2 \mathrm{H}, \mathrm{H}_{3,5}\right), 4.00\left(\mathrm{~s}, 3 \mathrm{H}, \mathrm{CO}_{2} \mathrm{Me}\right), 3.74(\mathrm{~s}, 1 \mathrm{H}, \mathrm{C} \equiv \mathrm{CH})$ $\mathrm{ppm}$; Data are in agreement with those previously reported in reference $4 \mathrm{~d}$.

Methyl 2-ethynyl-3-fluoroazulene-1-carboxylate (34): To a solution of $18(114 \mathrm{mg}, 0.491 \mathrm{mmol})$ and $\mathrm{K}_{2} \mathrm{CO}_{3}(216 \mathrm{mg}, 1.56$ $\mathrm{mmol})$ in $\mathrm{MeOH}(5 \mathrm{~mL})$ was added $31(202 \mathrm{mg}, 0.794 \mathrm{mmol})$. The resulting mixture was stirred at room temperature for $3 \mathrm{~h}$ under an Ar atmosphere. The reaction mixture was poured into water and extracted with AcOEt. The organic layer was washed with brine, dried with $\mathrm{Na}_{2} \mathrm{SO}_{4}$, and concentrated under reduced pressure. The residue was purified by silica gel column chromatography with toluene to give $34(20 \mathrm{mg}, 18 \%)$ as blue solid. M.p. $126-128{ }^{\circ} \mathrm{C}$; IR (ATR): $\mathrm{V}_{\max }=3279(\mathrm{w}), 3007(\mathrm{w})$, 2956 (w), 2107 (w), 1681 (s), 1595 (w), 1573 (w), 1540 (w), $1508(w), 1474(w), 1456(m), 1440(s), 1409(s), 1392(w), 1311$ $(w), 1291(w), 1235(\mathrm{~m}), 1214(\mathrm{~s}), 1160(\mathrm{w}), 1115(\mathrm{~m}), 1036(\mathrm{w})$, $1014(w), 963(w), 909(w), 891(w), 858(w), 839(w), 807(w)$, $781(\mathrm{~m}), 742(\mathrm{~m}), 680(\mathrm{w}), 665(\mathrm{~m}) \mathrm{cm}^{-1} ;{ }^{1} \mathrm{H}$ NMR $(500 \mathrm{MHz}$, $\left.\mathrm{CDCl}_{3}\right): \delta_{\mathrm{H}}=9.56\left(\mathrm{dd}, 1 \mathrm{H}, J=10.0,2.6 \mathrm{~Hz}, \mathrm{H}_{8}\right), 8.39(\mathrm{~d}, 1 \mathrm{H}, J=$ $\left.10.0 \mathrm{~Hz}, \mathrm{H}_{4}\right), 7.77\left(\mathrm{t}, 1 \mathrm{H}, J=10.0 \mathrm{~Hz}, \mathrm{H}_{6}\right), 7.46(\mathrm{t}, 1 \mathrm{H}, J=10.0$ $\left.\mathrm{Hz}, \mathrm{H}_{7}\right), 7.38$ (t, $1 \mathrm{H}, J=10.0 \mathrm{~Hz}, \mathrm{H}_{5}$ ), 3.99 (s, $\left.3 \mathrm{H}, \mathrm{CO}_{2} \mathrm{Me}\right), 3.90$ (s, $1 \mathrm{H}, \mathrm{C} \equiv \mathrm{CH}) \mathrm{ppm} ;{ }^{13} \mathrm{C}$ NMR $\left(125 \mathrm{MHz}, \mathrm{CDCl}_{3}\right): \delta_{\mathrm{C}}=164.9$, $153.7,151.6,141.2,140.3,134.1,133.7,128.0,126.5,115.9$, 111.9, 90.7, 76.4, 51.4 ppm; HRMS (EI-MS, positive): calcd for $\mathrm{C}_{14} \mathrm{H}_{9} \mathrm{FO}_{2}{ }^{+}[\mathrm{M}]^{+}$228.0582; found: 228.0593 .
2-Ethynylazulene (35): To a solution of 22 (78 mg, $0.500 \mathrm{mmol})$ and $\mathrm{K}_{2} \mathrm{CO}_{3}(213 \mathrm{mg}, 1.54 \mathrm{mmol})$ in $\mathrm{MeOH}(5 \mathrm{~mL})$ was added 31 (170 $\mathrm{mg}, 0.669 \mathrm{mmol})$. The resulting mixture was stirred at room temperature for $2 \mathrm{~h}$ under an $\mathrm{Ar}$ atmosphere. The reaction mixture was poured into water and extracted with hexane. The organic layer was washed with brine, dried with $\mathrm{Na}_{2} \mathrm{SO}_{4}$, and concentrated under reduced pressure. The residue was purified by silica gel column chromatography with hexane to give $\mathbf{3 5}$ as blue solid. M.p .64-66 ${ }^{\circ} \mathrm{C}$ (lit. $66{ }^{\circ} \mathrm{C}$ ) ${ }^{24}{ }^{1} \mathrm{H}$ NMR $(500 \mathrm{MHz}$, $\left.\mathrm{CDCl}_{3}\right): \delta_{\mathrm{H}}=8.27\left(\mathrm{~d}, 2 \mathrm{H}, J=9.8 \mathrm{~Hz}, \mathrm{H}_{4,8}\right), 7.57(\mathrm{t}, 1 \mathrm{H}, J=9.8 \mathrm{~Hz}$, $\left.\mathrm{H}_{6}\right), 7.45$ (s, $\left.2 \mathrm{H}, \mathrm{H}_{1,3}\right), 7.19\left(\mathrm{t}, 2 \mathrm{H}, J=9.8 \mathrm{~Hz}, \mathrm{H}_{5,7}\right), 3.48(\mathrm{~s}, 1 \mathrm{H}$, $\mathrm{C} \equiv \mathrm{CH})$ ppm; Data are in agreement with those previously reported in reference 24 .

2-Ethynyl-1-methyl-3-phenylazulene (36): To a solution of 26 (123 mg, $0.500 \mathrm{mmol}$ ) and $\mathrm{K}_{2} \mathrm{CO}_{3}(207 \mathrm{mg}, 1.50 \mathrm{mmol}$ ) in $\mathrm{MeOH}$ $(5 \mathrm{~mL})$ was added 31 (153 $\mathrm{mg}, 0.602 \mathrm{mmol})$. The resulting mixture was stirred at room temperature for $7 \mathrm{~h}$ under an $\mathrm{Ar}$ atmosphere. The reaction mixture was poured into water and extracted with AcOEt. The organic layer was washed with brine, dried with $\mathrm{Na}_{2} \mathrm{SO}_{4}$, and concentrated under reduced pressure. The residue was purified by silica gel column chromatography with hexane/AcOEt $(50: 1)$ to give $\mathbf{3 6}(50 \mathrm{mg}, 41 \%)$ as green oil. IR (ATR): $v_{\max }=3285(\mathrm{~m}), 3052(\mathrm{w}), 3023(\mathrm{w}), 2913(\mathrm{w}), 2094$ $(\mathrm{w}), 1682(\mathrm{w}), 1598(\mathrm{~m}), 1569(\mathrm{~m}), 1505(\mathrm{~m}), 1479(\mathrm{~m}), 1440(\mathrm{~m})$, $1386(\mathrm{~m}), 1294(\mathrm{w}), 1228(\mathrm{~m}), 1181(\mathrm{w}), 1144(\mathrm{w}), 1074(\mathrm{~m})$, $1026(\mathrm{~m}), 994(\mathrm{~m}), 950(\mathrm{~m}), 917(\mathrm{~m}), 890(\mathrm{~m}), 852(\mathrm{~m}), 823(\mathrm{~m})$, 763 (s), 739 (s), 715 (s), 698 (s) cm ${ }^{-1} ;{ }^{1} \mathrm{H}$ NMR $(500 \mathrm{MHz}$, $\left.\mathrm{CDCl}_{3}\right): \delta_{\mathrm{H}}=8.27\left(\mathrm{~d}, 1 \mathrm{H}, J=9.7 \mathrm{~Hz}, \mathrm{H}_{4}\right), 8.21(\mathrm{~d}, 1 \mathrm{H}, J=9.7 \mathrm{~Hz}$, $\left.\mathrm{H}_{8}\right), 7.65$ (d, 2H, J = 7.4 Hz, o-Ph), $7.52(\mathrm{t}, 3 \mathrm{H}, J=7.4 \mathrm{~Hz}, m, p-$ $\mathrm{Ph}), 7.47\left(\mathrm{t}, 1 \mathrm{H}, J=9.7 \mathrm{~Hz}, \mathrm{H}_{6}\right), 7.07\left(\mathrm{t}, 1 \mathrm{H}, J=9.7 \mathrm{~Hz}, \mathrm{H}_{5}\right), 7.01$ (t, $\left.1 \mathrm{H}, J=9.7 \mathrm{~Hz}, \mathrm{H}_{7}\right), 3.62(\mathrm{~s}, 1 \mathrm{H}, \mathrm{C} \equiv \mathrm{CH}), 2.76(\mathrm{~s}, 3 \mathrm{H}, \mathrm{Me})$ ppm; ${ }^{13} \mathrm{C}$ NMR $\left(125 \mathrm{MHz}, \mathrm{CDCl}_{3}\right): \delta_{\mathrm{C}}=138.8,136.6,136.2$, $136.0,135.5,134.8,131.6,130.7,128.8,128.7,128.3,126.8$, 123.5, 122.5, 87.8, 80.9, 11.5 ppm; HRMS (MALDI-TOF): calcd for $\mathrm{C}_{19} \mathrm{H}_{14}{ }^{+}[\mathrm{M}]^{+}$242.1090; found: 242.1106.

2-Ethynyl-6-isopropyl-1-methyl-3-phenylazulene (37): To a solution of $27(144 \mathrm{mg}, 0.500 \mathrm{mmol})$ and $\mathrm{K}_{2} \mathrm{CO}_{3}(211 \mathrm{mg}, 1.53$ $\mathrm{mmol})$ in $\mathrm{MeOH}(5 \mathrm{~mL})$ was added 31 (191 mg, $0.751 \mathrm{mmol})$. The resulting mixture was stirred at room temperature for $5 \mathrm{~h}$ under an $\mathrm{Ar}$ atmosphere. The reaction mixture was poured into water and extracted with $\mathrm{CH}_{2} \mathrm{Cl}_{2}$. The organic layer was washed with brine, dried with $\mathrm{Na}_{2} \mathrm{SO}_{4}$, and concentrated under reduced pressure. The residue was purified by silica gel column chromatography with hexane/AcOEt $(20: 1)$ to give $37(114 \mathrm{mg}$, $80 \%$ ) as green oil. IR (ATR): $v_{\max }=3293(\mathrm{~s}), 3057(\mathrm{w}), 2964(\mathrm{~m})$, $2928(w), 2869(w), 1936(w), 1599(w), 1574(s), 1507(w)$, $1461(\mathrm{~s}), 1447(\mathrm{~m}), 1415(\mathrm{w}), 1389(\mathrm{~m}), 1376(\mathrm{w}), 1362(\mathrm{w})$, $1329(w), 1301(w), 1256(m), 1245(w), 1182(w), 1156(w)$, $1121(w), 1074(w), 1041(m), 1026(w), 1011(w), 918(w), 882$ $(w), 858(w), 841(s), 765(m), 740(m), 719(s), 698(s), 675(w)$, $661(\mathrm{w}) \mathrm{cm}^{-1} ;{ }^{1} \mathrm{H}$ NMR $\left(500 \mathrm{MHz}, \mathrm{CDCl}_{3}\right): \delta_{\mathrm{H}}=8.23(\mathrm{~d}, 1 \mathrm{H}, \mathrm{J}=$ $\left.10.3 \mathrm{~Hz}, \mathrm{H}_{4}\right), 8.16\left(\mathrm{~d}, 1 \mathrm{H}, J=10.3 \mathrm{~Hz}, \mathrm{H}_{8}\right), 7.66$ (d, $2 \mathrm{H}, J=7.5$ $\mathrm{Hz}, o-\mathrm{Ph}), 7.51$ (t, $2 \mathrm{H}, J=7.5 \mathrm{~Hz}, m-\mathrm{Ph}), 7.39$ (t, $1 \mathrm{H}, J=7.5 \mathrm{~Hz}$, $p-\mathrm{Ph}), 7.02\left(\mathrm{~d}, 1 \mathrm{H}, J=10.3 \mathrm{~Hz}, \mathrm{H}_{5}\right), 7.02\left(\mathrm{~d}, 1 \mathrm{H}, J=10.3 \mathrm{~Hz}, \mathrm{H}_{7}\right)$, 3.59 (s, $1 \mathrm{H}, \mathrm{C} \equiv \mathrm{CH}), 3.00$ (sept, $1 \mathrm{H}, J=6.9 \mathrm{~Hz}, i-\mathrm{Pr}), 2.74$ (s, 3H, $\mathrm{Me}), 1.34(\mathrm{~d}, 6 \mathrm{H}, J=6.9 \mathrm{~Hz}, i-\mathrm{Pr}) \mathrm{ppm} ;{ }^{13} \mathrm{C}$ NMR $(125 \mathrm{MHz}$, $\left.\mathrm{CDCl}_{3}\right): \delta_{C}=161.0,135.9,135.7,135.3,134.62,134.56,131.4$, 130.6, 128.6, 128.2, 127.3, 126.7, 122.7, 121.7, 87.1, 81.1, 39.7, 
24.2, 11.4 ppm; HRMS (MALDI-TOF): calcd for $\mathrm{C}_{22} \mathrm{H}_{20}{ }^{+}[\mathrm{M}]^{+}$ 284.1560; found: 284.1557 .

\section{Acknowledgements}

This work was supported by JSPS KAKENHI Grant Number $17 \mathrm{~K} 05780$

Keywords: Azulene $\cdot$ Formylation $\cdot$ Alkynylation $・$ Crosscoupling $\cdot$ UV/Vis spectroscopy

[1] a) K.-P. Zeller, Azulene, in: Methoden der Organischen Chemie (Houben-Weyl), 4th ed. (Ed.: H. Kropf), Thieme, Stuttgart, Germany, 1985, vol. V, part 2c, p. 127-418; b) S. Ito, N. Morita, Eur. J. Org. Chem. 2009, 4567-4579; c) S. Ito, T. Shoji, N. Morita, Synlett 2011, 2279-2298; d) T. Shoji, S. Ito, Chem. Eur. J. 2017, 23, 16696-16709.

[2] a) A. G. Anderson, Jr., R. Scotoni, Jr., E. J. Cowles, C. G. Fritz, J. Org. Chem. 1957, 22, 1193-1196; b) A. G. Anderson, Jr., R. N. McDonald, J. Am. Chem. Soc. 1959, 81, 5669-5674; c) A. G. Anderson, Jr. R. G. Anderson, J. Org. Chem. 1962, 27, 3578-3581; d) A. G. Anderson, Jr. L. L. Replogle, J. Org. Chem. 1963, 28, 262-265; e) A. G. Anderson, Jr R. C. Rhodes, J. Org. Chem. 1965, 30, 1616-1619; f) T. Shoji, J. Higashi, S. Ito, K. Toyota, T. Asao, M. Yasunami, K. Fujimori, N. Morita, Eur. J. Org. Chem. 2008, 1242-1252; g) T. Shoji, S. Ito, J. Higashi, N. Morita, Eur. J. Org. Chem. 2011, 5311-5322.

[3] a) T. Shoji, S. Ito, M. Watanabe, K. Toyota, M. Yasunami, N. Morita, Tetrahedron Lett. 2007, 48, 3009-3012; b) T. Shoji, S. Ito, K. Toyota, N. Morita, Eur. J. Org. Chem. 2010, 1059-1069.

[4] Recently, Nielsen et al. have reported the functionalization of 5-position of azulenes by the palladium-catalyzed cross-coupling reactions: $V$. Mazzanti, M. Cacciarin, S. L. Broman, C. R. Parker, M. SchauMagnussen, A. D. Bond, M. B. Nielsen, Beilstein J. Org. Chem. 2012, 8, 958-966.

[5] a) M. Yasunami, T. Ueno, M. Yoshifuji, A. Okamoto, K. Hirotsu, Chem. Lett. 1992, 10, 1971-1974; b) A. A. S.Briquet, H.-J. Hansen, Helv. Chim. Acta 1994, 77, 1921-1939; c) H. Higuchi, J. Ojima, M. Yasunami, K. Fujimori, M. Yoshifuji, Tetrahedron Lett. 1994, 35, 1259-1262; d) S. Ito, A. Nomura, N. Morita, C. Kabuto, H. Kobayashi, S. Maejima, K. Fujimori, M. Yasunami, J. Org. Chem. 2002, 67, 7295-7302; e) S. Ito, S. Moriyama, M. Nakashima, M. Watanabe, T. Kubo, M. Yasunami, K Fujimori, N. Morita, Heterocycles, 2003, 61, 339-348; f) S. Ito, H. Hamazaki, Y. Hirasawa, A. Ohta, K. Fujimori, N. Tanaka, M. Shiro, Heterocycles, 2004, 62, 463-478; g) S. Hirakawa, J. Kawamata, Y. Suzuki, S. Tani, T. Murafuji, K. Kasatani, L. Antonov, K. Kamada, K Ohta, K. J. Phys. Chem. A 2008, 112, 5198-5207; h) S. Henkel, C. H. Pollok, T. Schleif, W. Sander, Chem. Eur. J. 2016, 22, 12479-12486.

[6] K. Hafner, K. L. Moritz, Justus Liebigs Ann. Chem. 1962, 656, 40-53.

[7] M. Saito, T. Morita, K. Takase, Bull. Chem. Soc. Jpn. 1980, 53, 36963700 .

[8] M. Fujinaga, K. Suetake, K. Gyoji, T. Murafuji, K. Kurotobi, Y. Sugihara, Synthesis 2008, 3745-3748.

[9] S. Ito, S. T. Kubo, T. N. Morita, Y. Matsui, T. Watanabe, A. Ohta, K. Fujimori, T. Murafuji, Y. Sugihara, A. Tajiri, Tetrahedron Lett. 2004, 45, 2891-2894.

[10] M. Yasunami, A. Chen, A. Noro, K. Takase, Chem. Lett. 1981, 10, 555-558.

[11] H. Meerwein, W. Florian, N. Schön,G. Stopp, Justus Liebigs Ann. Chem. 1961, 641, 1-39.

[12] K. Kurotobi, K. S. Kim, S. B. Noh, D. Kim, A. Osuka, Angew. Chem. Int. Ed. 2006, 45, 3944-3947.

[13] T. O. Leino, M. Baumann, J. Yli-Kauhaluoma, I. R. Baxendale, E. A. A. Wallén, J. Org. Chem. 2015, 80, 11513-11520.

[14] CCDC 1580641 (enamine from 5), CCDC 1561683 (compound 16), CCDC 1522054 (compound 23), CCDC 1580643 (compound 26) and CCDC 1580642 (compound 30) contain the supplementary crystallographic data for this paper. These data are provided free of charge by The Cambridge Crystallographic Data Centre.

[15] The 1-azulenyl group usually behaves as an electron-donating group, while the 2-, 4- and 6-azulenyl groups act as electron-withdrawing groups; see reference 1.

[16] T. Shoji, S. Ito, S. T. Okujima, J. Higashi, R. Yokoyama, K. Toyota, M. Yasunami, N. Morita, Eur. J. Org. Chem. 2009, 1554-1563.

[17] a) P. W. Yang, M. Yasunami, K. Takase, K.; Tetrahedron Lett. 1971, 4275-4278; b) Yasunami, M.; A. Chen, P. W. Yang, K. Takase, Chem Lett. 1980, 9, 579-582; c) T. Shoji, A. Maruyama, M. Tanaka, D. Nagai, E. Shimomura, K. Fujimori, S. Ito, T. Okujima, K. Toyota, M. Yasunami, ChemistrySelect 2016, 1, 49-56.

[18] M. Porsch, G. Sigl-Seifert, J. Daub, Adv. Mater. 1997, 9, 635-639.

[19] A. L. Crombie, J. L. Kane, Jr., K. M. Shea, R. L. Danheiser, J. Org. Chem. 2004, 69, 8652-8668.

[20] N. C. Thanh, M. Ikai, T. Kajioka, H. Fujikawa, Y. Taga, Y. Zhang, S. Ogawa, H. Shimada, Y. Miyahara, S. Kuroda, M. Oda, Tetrahedron 2006, 62, 11227-11239.

[21] a) S. Ito, M. Ando, A. Nomura, N. Morita, C. Kabuto, H. Mukai, K. Ohta, J. Kawakami, A. Yoshizawa, A. Tajiri, J. Org. Chem. 2005, 70, 39393949; b) M. Koch, O. Blacque, K. Venkatesan, Org. Lett. 2012, 14 1580-1583; c) M. Koch, O. Blacque, K. Venkatesan, J. Mater. Chem. C 2013, 1, 7400-7408; d) T. Shoji, E. Shimomura, M. Maruyama, S. Ito, T. Okujima, N. Morita, Eur. J. Org. Chem. 2013, 957-964; e) T. Shoji, S. Ito, T. Okujima, N. Morita, Chem. Eur. J. 2013, 19, 5721-5730; f) T. Shoji, M. Maruyama, E. Shimomura, A. Maruyama,S. Ito, T. Okujima, K. Toyota, N. Morita, J. Org. Chem. 2013, 78, 12513-12524; g) T. Shoji, M. Maruyama, A. Maruyama, S. Ito, T. Okujima, K. Toyota, Chem. Eur. J. 2014, 20, 11903-11912; h) E. Puodziukynaite, H.-W. Wang, J. Lawrence, A. J. Wise, T. P. Russell, M. D. Barnes, T. Emrick, J. Am. Chem. Soc. 2014, 136, 11043-11049.

[22] a) D. Seyferth, P. Hilbert, R. S. Marmor, J. Am. Chem. Soc. 1967, 89 , 4811-4812; b) D. Seyferth, R. S. Marmor, P. Hilbert, J. Org. Chem. 1971, 36, 1379-1386; c) J. C. Gilbert, U. Weerasooriya, J. Org. Chem. 1979, 44, 4997-4998; d) J. C. Gilbert, U. Weerasooriya, J. Org. Chem. 1982, 47, 1837-1845.

[23] a) S. Ohira, Synth. Commun. 1989, 19, 561-564; b) S. Müller, B. Liepold, G. J. Roth, H. J. Bestmann, Synlett 1996, 521-522; c) G. J. Roth, B. Liepold, S. G. Muller, H. J. Bestmann, Synthesis 2004, 59-62.

[24] D. F. Taber, S. Bai, P. Guo, Tetrahedron Lett. 2008, 49, 6904-6906.

[25] K. H. H. Fabian, A. H. M. Elwahy, K. Hafner, Eur. J. Org. Chem. 2006 791-802. 


\section{FULL PAPER}

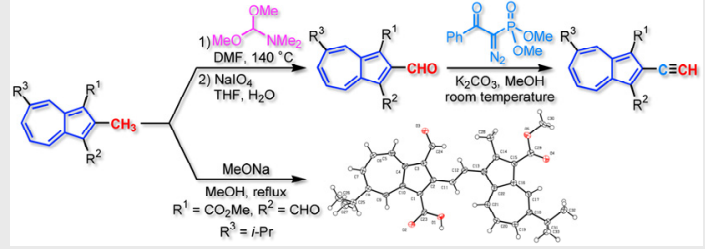

2-Formylazulene derivatives were obtained in good yields by the reaction of 2methylazulenes with $\mathrm{N}, \mathrm{N}$-dimethylformamide dimethyl acetal, followed by oxidative cleavage of intermediately formed enamines with $\mathrm{NalO}_{4}$. 2-Formylazulenes obtained by the reaction were also transformed to 2-ethynylazulenes in good yields by modified Seyferth-Gilbert reaction.

\section{Azulene Chemistry}

Taku Shoji, * Takanori Araki, Nanami lida, Yoshiaki Kobayashi, Akira Ohta, Ryuta Sekiguchi, Shunji Ito, Shigeki Mori, Tetsuo Okujima, and Masafumi Yasunami

Page No. - Page No.

Molecular Transformation of 2-

Methylazulenes: An Efficient and Practical Synthesis of 2-Formyl- and 2-Ethynylazulenes 